\title{
The Natural Products and Pharmacological Biodiversity of Brown Algae from the Genus Dictyopteris
}

\author{
Mohammed I. Rushdi ${ }^{1}$, Iman A. M. Abdel-Rahman ${ }^{1}$, Hani Saber ${ }^{2}$, Eman Zekry Attia ${ }^{3}$, Usama \\ Ramadan Abdelmohsen ${ }^{3,4 *}$. \\ ${ }^{1}$ Department of Pharmacognosy, Faculty of Pharmacy, South Valley University, 83523, Qena, Egypt. \\ ${ }^{2}$ Department of Botany and Microbiology, Faculty of Science, South Valley University, 83523, Qena, Egypt. \\ ${ }^{3}$ Department of Pharmacognosy, Faculty of Pharmacy, Minia University, 61519 Minia, Egypt. \\ ${ }^{4}$ Department of Pharmacognosy, Faculty of Pharmacy, Deraya University, Universities Zone, 61111 New Minia \\ City, Egypt.
}

*Corresponding author: Usama Ramadan Abdelmohsen, email: usama.ramadan@mu.edu.eg; Tel.: +2-862347759; Fax: +2-86-2369075 (URA).

Received July 31 , 2021; Accepted October 19 th $^{\text {th }} 2021$.

DOI: http://dx.doi.org/10.29356/jmcs.v66i1.1639

\begin{abstract}
Genus Dictyopteris is an important genus among marine seaweeds and is excessively distributed and known by its ocean smell due to its secondary metabolites including $\mathrm{C}_{11}$-hydrocarbons and sulfur compounds. This chemical feature is responsible for its interesting biological properties. This review detected the literature from 1959 to 2021 on the genus Dictyopteris and revealed the secondary metabolites, together with biological activities of the genus Dictyopteris to create the base for additional studies on its clinical and pharmaceutical applications.
\end{abstract}

Keywords: Marine; natural products; brown algae; Dictyopteris; Phaeophyceae.

Resumen. El género Dictyopteris es un género importante entre las algas marinas y está excesivamente distribuido y conocido por su olor a océano debido a sus metabolitos secundarios que incluyen hidrocarburos $\mathrm{C}_{11} \mathrm{y}$ compuestos de azufre. Esta característica química es responsable de sus interesantes propiedades biológicas. Esta revisión detectó la literatura de 1959 a 2021 sobre el género Dictyopteris y reveló los metabolitos secundarios, junto con las actividades biológicas del género Dictyopteris, para crear la base para estudios adicionales sobre sus aplicaciones clínicas y farmacéuticas.

Palabras clave: Marino, productos naturales, algas marrones, Dictyopteris, Phaeophyceae.
Abbreviations
DCM: Dichloromethane
PUFAs: Polyunsaturated fatty acids
DPPH: 2,2-diphenyl-1-picrylhydrazyl
IC50: Half-maximal inhibitory
concentration
GAE: Gallic acid equivalent
HeLa: Cervical cancer cell line
APTT: Activated partial thromboplastin time
FRAP: Ferric reducing antioxidant power assay
CE: Vitamin C equivalent 
LPS: Lipopolysaccharide

TNF- $\alpha$ : Tumor necrosis factor- $\alpha$

NO: Nitric oxide

IL-6: Interleukin-6

KB: Ubiquitous keratin-forming tumor cell

line

LDH: Lactate dehydrogenase

PARP: Poly ADP (Adenosine Diphosphate)-

Ribose Polymerase

p21: Tumor protein $\mathrm{p} 21$

p53: Tumor protein $\mathrm{p} 53$

Bax: Apoptosis regulator Bax, gene

Bcl-2: B-cell lymphoma-2 gene

LDA: Lithium diisopropylamide

p38: Tumor protein $\mathrm{p} 38$

MAPK: Mitogen-activated protein kinases

YAP: Yes-associated protein

CDK6: Cyclin-dependent kinase 6

MTT: 3-[4,5-dimethylthiazol-2-yl]-2,5diphenyltetrazolium bromide

AchE: Acetylcholinesterase

MMP-1: Matrix metalloproteinase-1 protein

MMP-2: Matrix metalloproteinase-2 protein

MMP-3: Matrix metalloproteinase-3 protein

MMP-9: Matrix metalloproteinase-9 protein

Sirt-1: Sirtuin 1 gene

Caco-2: Human colon cancer cell line

HDFs: Human dermal fibroblasts

HepG2: Hepatocarcinoma cell line

Bel-7402: Hepatoma cell line

PC-3: Prostate adenocarcinoma cell line

Ketr 3: Kidney cancer cell line

MCF 7: Breast cancer cell line

UVB: Artificial ultraviolet light

TGF-ק1: Transforming growth factor beta 1

AP-1: Activator protein 1

MiaPaca-2: Pancreas cancer cell line

A-549: Lung cancer cell line
SNU-5: Stomach cancer cell line

AMPK: Adenosine monophosphate-activated protein kinase

HL-60: Human promyelocytic leukaemia

cell line

HT-29: Human colon carcinoma cell line

B16F10: Murine melanoma cell line

HCT-8: Colorectal adenocarcinoma cell line

BGC-823: Gastric cancer cell line

ADP: Adenosine diphosphate

LC 50: Lethal concentration 50

HSV-1: Herpes simplex virus-1

SPs: Sulfated polysaccharides

DW: Dry wight

CAE: Catechin equivalents

QE: Quercetin equivalent

GC-MS: Gas chromatography-mass spectrometry

IL-12: Interleukin 12

iNOS: NO converting enzyme

MRC1: Mannose receptor C-Type 1

RPMI-7951: Human melanoma cell line

MIC: Minimum inhibitory concentration

3T3-L1: Mouse pre-adipocytes cell line

SW480: Human colon adenocarcinoma cell

line

PTP1B: Protein tyrosine phosphatase-1B

LXRa: Liver X receptor alpha protein

LXRß: Liver X receptor beta protein

eNOS: Endothelial nitric oxide synthase

cPLA2: Cytosolic phospholipase A2

PI3K: Phosphoinositide 3-kinase

ERK1/2: Extracellular signal-regulated kinases

LPC: Lyso phosphatidyl choline

Nrf2-ARE: Nuclear factor erythroid 2related factor 2

EC50: Half maximal effective concentration.

\section{Introduction}

Marine natural products which were detected in macroalgae, sponges, and soft corals, are representing a great source of biomolecules with a wide spectrum of effects useful in different biotechnological fields. Numerous species are distributed throughout the Red sea, with insufficient information regarding seagrass, seaweeds and soft corals of Egypt urges. Further exploration and robust taxonomic work are required for the conservation of these important ecosystems. Green, brown, and red macroalgal crude extracts, and their fractions or purified components, have been reported to exhibit various pharmacological activities [1]. Genus Dictyopteris is widely distributed in the marine environment of tropical, sub-tropic, and temperate regions. Dictyopteris J.V. Lamouroux was first proposed by Lamouroux in 1809. It includes species with dichotomously 
branched planar thalli with a definite central midvein. Thalli are connected to rhizoidal holdfast, up to $60 \mathrm{~cm}$ long with sub dichotomously to laterally branch from $0.5 \mathrm{~mm}$ to $25 \mathrm{~mm}$ broad. Growth occurs via a row of meristematic cells that lies in a shallow depression on the branch apex. This genus comprises 34 species with significant anatomical and morphological variation [2,3]. The Dictyopteris is a smelly type of seaweed, it is known for its characteristic odor due to the presence of non-isoprenoid $\mathrm{C}_{11}$-hydrocarbons and its essential oil which represents about $40 \%$ of the lipid content [4]. Female gametes of marine brown algae release and/or attract their conspecific males by chemical signals. The majority of these compounds are nonfunctionalized acyclic, unsaturated, and/or alicyclic $\mathrm{C}_{11}$ hydrocarbons. Concentrations for release and attraction are generally observed in the range of 1-1000 pmol. The blends may contain mixtures of enantiomers and various configurational isomers of the genuine pheromones. Higher plants produce the $\mathrm{C}_{11}$ hydrocarbons from dodeca3,6,9-trienoic acid; brown algae exploit the family of eicosanoids for biosynthesis of the same compounds. The biosynthetic routes comprise several spontaneously occurring [1.7]-hydrogen shifts, pericyclic reactions such as [3.3]-sigmatropic rearrangements, and electrocyclic ring closures. All pheromones are (a)biotically degraded by ubiquitous oxidative pathways involving hydroxyl radicals or singlet oxygen, which may be produced through the agency of heavy metals, huminic acids, or light. [5]. Extracts and their fractions derived from Dictyopteris have been reported to exhibit several biological activities including antifungal, antioxidant, antiinflammatory, tyrosinase inhibitors, alpha-amylase inhibitors, and small hemolysis activities. This review reports the natural products from the genus Dictyopteris and revealed their pharmacological activities and the mechanism of action whenever applicable.

\section{Chemistry and pharmacological biodiversity of genus Dictyopteris Dictyopteris acrostichoides (J. Agardh) Bornet 1885}

Unique $\mathrm{C}_{11} \mathrm{H}_{16}$ hydrocarbons with $(E)$ - or $(E, E)$-configuration at the double bond(s) within the longer side chain were detected as main products of GC-MS of D. acrostichoides. 1-(Cyclopentenyl) hexa-1E,3Zdiene (1), 1-(cyclopentenyl) hexa-1E,3E-diene (2) and 4-[(1E)-hexenyl]cyclopentene (3), (5R)-1-butyl-5ethenylcyclopentene (4), $(3 E, 5 E)$-undeca-1,3,5-triene (5), (3E,5Z)-undeca-1,3,5-triene (6), (3E,5Z,8Z)-undeca1,3,5,8-tetraene (7), $(1 R, 2 R)$-1-ethenyl-2-[(1E)-hex-1-en-1-yl]cyclopropane (8) and $(1 R, 2 R)$-1-ethenyl-2[(1E,3Z)-hexa-1,3-dien-1-yl]cyclopropane (9) were detected in the Southern Australian D. acrostichoides, (Fig. 1) [6]. Brown algae have long been recognized to possess several pheromone compounds with diverse functions contributing to the reproductive cycle, which have been studied significantly throughout some species. $D$. acrostichoides showed the largest number of $\mathrm{C}-11$ pheromones. Those compounds are produced by the organism with the number one characteristic of attracting male gametes to complete sexual reproduction, however, a few have additionally been proven to characteristic as effective anti-predation agents or might also additionally be used to intervene with different pheromone communique structures of competing alga [7]. n-Hexane and DCM extracts of $D$. acrostichoides, collected from Probolinggo, (Indonesia), displayed anti-microbial activities against $V$. alginolaticus (mean inhibition zone $=12$ and $8 \mathrm{~mm}$, respectively) and $V$. harveyii (mean inhibition zone $=10$ and $6 \mathrm{~mm}$, respectively), while the ethyl acetate extract did not have anti-microbial activity against $V$. harveyii and $V$. alginolaticus [8]. 


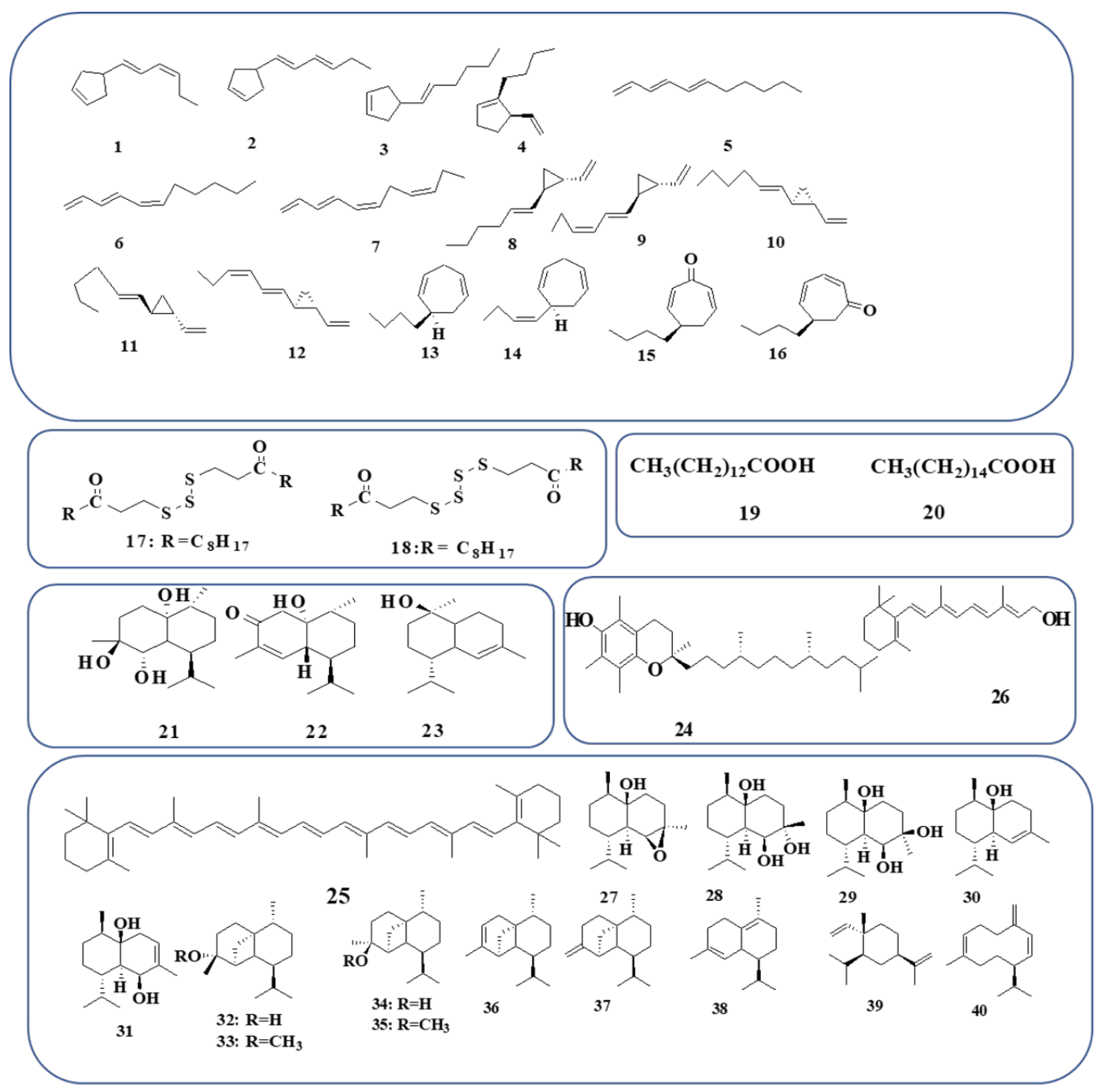

\section{Dictyopteris australis (Sonder) Askenasy 1888}

Dictyopterene A (10) and its isomer (11), dictyopterene B (12), dictyopterene $\mathrm{C}^{\prime}$ (13), dictyopterene D' (14), dihydrotropones (15), and $S$-(3-oxoundecyl) thioacetate (16) were detected in GC-MS from D. australis and D. plagiogramma collected from Hawaiian coasts [9-11]. The thermal rearrangements of the transdivinylcyclopropanes and cis-divinylcyclopropane to give cycloheptadiene have been detected. The transdivinylcyclopropane-cycloheptadiene rearrangements occurred under irradiation by a mercury lamp in benzene at $40^{\circ}$. These low-temperature in vitro rearrangements suggest that the biosynthesis of the cycloheptadienes in Dictyopteris (dictyopterenes $\mathrm{C}^{\prime}(\mathbf{1 3})$ and dictyopterenes $\mathrm{D}^{\prime}(\mathbf{1 4})$ may proceed by the same reactions [12].

While bis-(3-oxoundecyl) trisulfide (17) and bis-(3-oxoundecyl) tetrasulfide (18), were detected in the GC-MS of $D$. australis and D. plagiogramma collected from Hawaiian coasts (Fig. 1) [13]. Highly stereoselective synthesis of dictyopterene $C^{\prime}(\mathbf{1 3})$ and its enantiomer from the diastereomeric $\gamma$ hydroxyphenylethylamide intermediates have been reported [14]. Starting from the optically active 5trimethylsilyl-2-cyclohexene-1-one derivatives, the 1,3-cyclohexadiene and 1,4-cycloheptadiene were 
synthesized by using silicon-mediated 1,4-elimination as a key step [15]. Fatty acids Cl4:0, C16:0, Cl6:1, Cl8:3 (n-3), C18:4 (n-3), C20:5 (n-3) and C22:6 (n-3) were detected in D. australis collected from several sites of Australian shores. D. australis had characteristic fatty acids contents diversity between whole algae, upper section and lower section of alga. It had a higher proportion of total PUFA (n-3 and n-6). The most abundant saturated fatty acids were myristic acid (C14:0) (19) and palmitic acid (C16:0) (20) [16]. The methanolic extracts of $D$. australis and $D$. delicatula, Lamouroux collected from Natal (Brazil), were reported as antioxidants and showed very high $\mathrm{DPPH}$ radical scavenging activity $\left(\mathrm{IC}_{50}=1.60 \pm 0.013\right.$ and $0.66 \pm$ $0.002 \mathrm{mg} / \mathrm{mL}$, respectively) due to the total phenolic content $(13.19 \pm 0.32$ and $21.34 \pm 0.428 \mathrm{GAE} \mathrm{mg} / \mathrm{g}$ of total methanolic extract, severally). Dose-dependent cytotoxic activities were detected against the brine shrimp A. salina. The highest cytotoxic activity of D. australis was at a dose of $100 \mu \mathrm{g} / \mathrm{mL}$ in 18 and $24 \mathrm{~h}$ and caused complete mortality of the brine shrimp at a dose of $500 \mu \mathrm{g} / \mathrm{mL}$ in $24 \mathrm{~h} \mathrm{[17].}$

\section{Dictyopteris delicatula J.V. Lamouroux 1809}

Polysaccharides in D. delicatula, collected from the Natal coast (Brazil), were detected to have a dosedependent antioxidant activity and suppress HeLa proliferation. The percentage of inhibition ratio was calculated for antiproliferative activity $(61.0 \%, 2 \mathrm{mg} / \mathrm{mL})$. The antiproliferative efficacy of these polysaccharides was related to the sulfate content. The hetero fucans detected in $D$. delicatula exhibited anticoagulant activity by APTT test only, it was recommended that inhibition was due to both the intrinsic and common pathways of coagulation [18]. Six sulfated polysaccharides were detected in D. delicatula, collected from Natal (Brazil). The fucans F $0.5 \mathrm{v}$ and F $0.7 \mathrm{v}$ at $1.0 \mathrm{mg} / \mathrm{mL}$ have high $\mathrm{Fe}^{+3}$ chelating activity (45\%), whereas fucans $\mathrm{F} 1.3 \mathrm{v}$ at $0.5 \mathrm{mg} / \mathrm{mL}$ showed considerable reducing power $(53.2 \%)$ of the activity of vitamin $\mathrm{C}$. The fucan $\mathrm{F} 1.5 \mathrm{v}$ was detected as an anticoagulant. The antiproliferative activity of $\mathrm{F} 1.3 \mathrm{v}$ was much higher than F $0.7 \mathrm{v}$, it displayed inhibition of almost $100 \%$ of (HeLa) cell proliferation [19]. The antioxidant potentials by the FRAP assay for DCM-methanol (50:50) and $\mathrm{H}_{2} \mathrm{O}$ extracts of $D$. delicatula detected from the Jaguaribe Beach, did not show significant differences between solvents (DCM: MeOH, $5.28 \pm 0.12 \mathrm{mg} \mathrm{GAE} / \mathrm{g} \mathrm{CE}$ and $\mathrm{H}_{2} \mathrm{O}, 4.33 \pm 0.20$-mg GAE/g CE) [20]. 4 $\beta, 5 \alpha$-Dihydroxycubenol (21), cubenol-3-one (22) and ( \pm )-torreyol (23) were detected in $D$. delicatula Lamouroux (Fig. 1) [21]. Aqueous extract of D. delicatula showed weak antiparasitic activities on the life cycle of the Neobenedenia sp. and $M$. ectoparasite, besides, it reduced hatching success to $3 \%$ compared to $99 \%$ for the seawater as control [22]. $\alpha$-Tocopherol (24) $\beta$-carotene (25), and vitamin A (26) were detected in the methanolic extract of $D$. delicatula Lamouroux, collected during low tide from Guajiru Beach and Trairi- Ceará (Brazil). $\alpha$ - Tocopherol (24) $\beta$-carotene (25), and vitamin A (26) were quantified, and their contents were $26.562 \pm 3.627,0.266 \pm 0.198$ and $0.044 \pm 0.033 \mu \mathrm{g} / \mathrm{g}$ fresh weight, severally [23].

\section{Dictyopteris divaricata (Okamura) Okamura 1932}

The high content of an uncommon fatty acid C22 polyunsaturated fatty acids, C16:1(n-5), PUFAs (n6), and PUFAs (n-3) were detected in D. divaricate and collected from Great Bay (Japan). The C16: 1(n-5) acid was detected in glycolipids and betaine lipids fractions [24]. The average molecular weight of polysaccharides detected in $D$. divaricate and collected from Qingdao (China), was calculated (58.05kDa) and the GC/MS analysis detected fucose, xylose, mannose, glucose, and galactose (molar ratio, 4.45: 2.74: 1.00: 2.94: 1.35). The identified polysaccharide exhibited antioxidant activities and possessed the potential immune stimulant response of LPS-stimulated RAW264.7 cells [25]. Ethyl acetate fractions of D. divaricata and D. prolifera were reported for their inhibitory effects on pro-inflammatory mediators and cytokines such as prostaglandin $\mathrm{E}_{2}$, TNF- $\alpha$, NO, and IL-6. D. divaricata and $D$. prolifera extracts were potently dose-dependently repressing LPSstimulated $\mathrm{NO}$ production $\left(\mathrm{IC}_{50}=18.0\right.$ and $38.36 \mu \mathrm{g} / \mathrm{mL}$, respectively) and suppressed the expression of inducible NO synthase and cyclooxygenase- 2 at the protein level in the RAW 264.7 cells. Besides, $D$. divaricata and D. prolifera reduced the levels of TNF- $\alpha\left(\mathrm{IC}_{50}=16.11\right.$ and $28.21 \mu \mathrm{g} / \mathrm{mL}$, respectively) and IL-6 $\left(\mathrm{IC}_{50}=37.35\right.$ and $80.08 \mu \mathrm{g} / \mathrm{mL}$, respectively). Also, the total phlorotannin content was measured as phloroglucinol equivalents, which were detected $(92.0 \mu \mathrm{g} / \mathrm{mg})$ for D. divaricata, and $(57.2 \mu \mathrm{g} / \mathrm{mg})$ for D. prolifera [26]. The hexane extracts of $D$. divaricata collected from the coast of China had strong cytotoxic activities against KB cells $\left(\mathrm{IC}_{50}<4.40 \mu \mathrm{g} / \mathrm{mL}\right.$ ) [27]. An extract of chloroform: methanol (1:2) of, fresh $D$. divaricate collected from Qingdao (China), was detected as alpha-glucosidase inhibitors and calculated inhibition percentage was 62.78 
$\%$ at $79.6 \mu \mathrm{g} / \mathrm{ml}$ [28]. Aqueous D. divaricata capped gold nanoparticles (DD-GNPs) attenuated oxygen and glucose deprivation/reoxygenation (OGD/R)-stimulated neuronal injury by inhibited OGD/R-induced release of LDH, loss of cell viability, and production of reactive oxygen species. This neuroprotection was accompanied by regulation of apoptosis-related proteins, as indicated by decreased levels of cleaved-caspase-3, cleavedPARP, cleaved-caspase-9, p21, p53, and Bax, as well as an increased level of Bcl-2, as evidenced by reduced

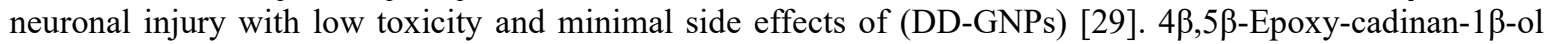
(27) is an epoxy-cadinane sesquiterpene, cubenol-3-one (22), torreyol (23), cadinan-1,4,5-triol (28), 4 $\alpha, 5 \beta$ dihydroxycubenol (29), cubenol (30), cadinan-3-ene-1,5S-diol (31), (Fig. 1), were detected in $\mathrm{CHCl}_{3}-\mathrm{MeOH}$ $(1: 1, \mathrm{v} / \mathrm{v})$ extract of $D$. divaricata collected from Yantai (China) [30]. Epicubebol (32), cubebol (34), with two minor methyl ether (33) and (35), (-)- $\alpha$-cubebene (36), (-)- $\beta$-cubebene (37), $(+)-\delta$-cadinene (38), (Fig. 1$)$, were detected in methanol extract of fresh $D$. divaricate collected from Okamura (Japan) where epicubebol (32), was detected as the major constituent [31]. Syntheses of (-)-menthone with LDA and $\mathrm{HCO}_{2} \mathrm{CH}_{2} \mathrm{CF}_{3}$ prevents loss of configurational integrity at the isopropyl group and syntheses of hydroxymethylenementhone. Lithium 2,2,6,6-tetramethylpiperidide-induced intramolecular cyclopropanation of derived unsaturated terminal epoxide and chlorohydrin generates a substituted tricyclo[4.4.0.01,5]decan-4-ol 18, which is used in a concise synthesis of (-)-cubebol (34) [32]. Cubenol (30) (over $95 \%$ ) instead of the $\mathrm{C}_{11}$-compounds was detected in the GC-MS from essential oils of $D$. diuaricata collected from two different coasts (Japan) with a small amount of $\beta$-elemene (39) and germacrene D (40) [33]. $\beta$-Elemene (39) had been synthesized starting from geranyl acetone by a short route produced cyclization of 3-isopropenyl-6-methyl-10-oxo-6E-undecenal as the key step in the presence of titanium as a catalyst [34]. $\beta$-Elemene (39), has been used as an antitumor drug for different tumors, including glioblastoma. However, the anti-proliferation of glioblastoma cells induced by $\beta$-elemene (39), was dependent on p38 (MAPK) activation. Treatment of glioblastoma cell lines with $\beta$-elemene (39), led to phosphorylation of p38 (MAPK), cell-cycle arrest in G0/G1 phase, and inhibition of proliferation of these cells. The growth of glioblastoma cell-transplanted tumors in nude mice was inhibited by intraperitoneal injection of $\beta$-elemene (39), a marked down-regulation of YAP expression in glioma cells, which is a key transcriptional co-activator in multiple cancers. Moreover, CDK6, which is a known downstream target of YAP, was decreased in glioma cells [35, 36]. 4 $\beta, 5 \alpha$-Dihydroxycubenol (21), (-)-torreyol (23), dictyvaric acid (41) 3-farnesyl-p-

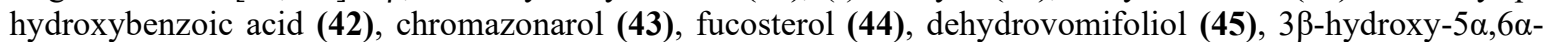
epoxy-7-megastigmen-9-one (46), loliolide (47) and isololiolide (48) (Fig. 2) were detected in the ethanol

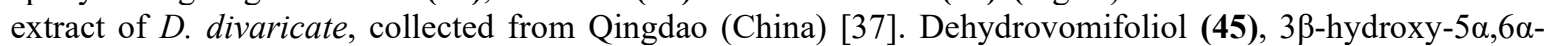
epoxy-7-megastigmen-9-one (46), loliolide (47), isololiolide (48), (3R)-4-[(2R,4S)-2hydroxy-2,6,6trimethylcyclohexylidene]-3- buten-2-oneiol and, $(3 R)-4-[(2 R, 4 S)$-4-acetoxy-2-hydroxy-2,6,6trimethylcyclohexylidene]-3- buten-2-one were isolated by reversed phase HPLC from extract of $D$. divaricata, collected from Qingdao. Compounds were tested for antitumor activity by the MTT method and AchE inhibitory activity [38] where loliolide (47) exhibited photoprotective, anti-wrinkling, antiaging, antiinflammatory, anti-apoptotic, and anti-scratching effects in human keratinocytes. Loliolide (47) could decrease the expression of the collagen degradation-related genes (MMP-1, MMP-2, MMP-3, and MMP-9), inflammatory genes TNF- $\alpha$, and restoring Sirt-1 expression [39]. Loliolide (47) has been reported to downregulate acetylcholinesterase activity and repressed cell proliferation in Caco-2 cells. Loliolide (47) rescued cellular senescence in HDFs and might be helpful for the developed treatment of age-associated diseases [40]. Isololiolide (48) exerted a selective cytotoxic activity on HepG2 cells and induced apoptosis through the modulation of apoptosis-related proteins [41]. Phenyl acetylamine, palmitic acid (20), 4 $3,5 \alpha-$ dihydroxycubenol (21), ( \pm )-torreyol (23), 3 farnesyl-p-hydroxybenzoic acid (42), chromazonarol (43), fucosterol (44), and 4-hydroxybenzoic acid (49) were detected in ethanol extract of $D$. divaricata. All compounds were inactive $\left(\mathrm{IC}_{50}>10 \mu \mathrm{g} / \mathrm{mL}\right.$ ) against KB, Bel-7402, PC-3, Ketr 3 and MCF 7, (Fig. 2) [42]. Fucosterol (44) was detected as a trace in ethanol extract of $D$. divaricata collected in Ulleungdo Island, Korea [43]. Fucosterol (44) was detected as a protectant against skin photodamage by UVB-irradiated of normal human dermal fibroblasts. It regulated type I procollagen expression and MMP- 1 by modulating TGF- $\beta 1$ and AP-1 signaling, and that MMP-1 activation are correlated with IL-6 [44]. For skin whitening or skin moisturizing formulation, fucosterol (44) have an excellent whitening effect by inhibiting melanin generation and tyrosinase activity which lead to an excellent moisturizing function by forming dead skin cell membranes, promoting the differentiation of dead skin cells, and generating natural moisturization factors [45]. Furthermore, 
fucosterol (44) was detected as anticancer against various type of human cancer cell lines such as (MiaPaca-2, $\left.\mathrm{IC}_{50}=250 \mu \mathrm{M}\right),\left(\mathrm{A}-549, \mathrm{IC}_{50}=125 \mu \mathrm{M}\right),\left(\mathrm{PC}-3, \mathrm{IC}_{50}=125 \mu \mathrm{M}\right),\left(\mathrm{MCF}-7, \mathrm{IC}_{50}=125 \mu \mathrm{M}\right),\left(\mathrm{SNU}-5, \mathrm{IC}_{50}=125\right.$ $\mu \mathrm{M})$ and $\left(\mathrm{HeLa}, \mathrm{IC}_{50}=40 \mu \mathrm{M}\right)$ [46]. As well, it was detected for the antiadipogenic effect by preventing adipogenesis though mediating both AMPK and catenin-signaling pathways [1, 47]. Fucosterol (44) was detected in the ethyl acetate extract of $D$. divaricata collected from Jeju coastal, ethyl acetate extract has cytotoxic activity against HL-60, HT-29, B16F10 and A549 cell lines. Ethyl acetate extracts were induced cell shrinkage, cell membrane blebbing and formation of apoptotic bodies [48, 49]. 4-Hydroxybenzoic acid (49) displayed antimicrobial activities against $S$. aureus, $S$. cerevisiae, $S$. epidermidis, $M$. luteus, L. plantarum, $S$. typhimurum, L. mesenteroides, E. coli, B. subtilis, S. mutans, P. syringaepv., Agrobacterium, P. aeruginosa, $P$. syringae, E. carotovora, X. campestris, V. vulnificus, and C. albicans $\left(\mathrm{IC}_{50}\right.$ ranging from 247 to $1380 \mu \mathrm{g} / \mathrm{mL}$ ) [50]. 4-Hydroxybenzoic acid (49) was detected for its hypoglycemic activities in normal rats after an oral administration $(5 \mathrm{mg} / \mathrm{kg})$, it increased serum insulin levels and liver glycogen content in normal rats [51]. 1,4 epoxy muurolan- $5 \beta$-ol (50) was detected in extract of a mixture of $\mathrm{CHCl}_{3}$ and $\mathrm{MeOH}(1: 1, \mathrm{v} / \mathrm{v})$ of $D$. divaricata collected from Yantai (China). It was tested against brine shrimp A. salina and displayed no toxicity at 100 $\mu \mathrm{g} / \mathrm{mL}$ (Fig. 2) [52]. 1-Bromoselin-4(14),11-diene (51) and 9-bromoselin-4(14),11-diene (52), cadalene (53), $\alpha$-selinene (54), $\beta$-selinene (55), $\beta$-dictyopterol (56), and cyperusol C (57) were detected in $\mathrm{CHCl}_{3}-\mathrm{MeOH}(1: 1$, $\mathrm{v} / \mathrm{v}$ ) extract of $D$. divaricate, collected from Yantai (China) [53]. While $\beta$-dictyopterol (56), $\alpha$-dictyopterol (58),

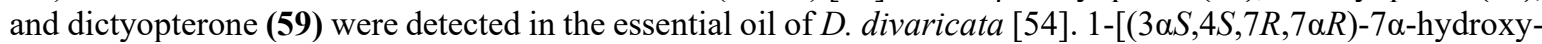

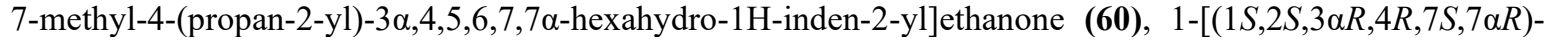
1,3 $\alpha$-dihydroxy-4-methyl-7-(propan-2-yl) octahydro-1H-inden-2-yl]ethanone $\quad$ (61), $\quad 1$ -

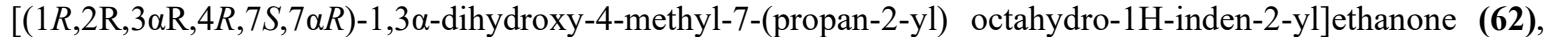
$(4 S, 7 R, 7 \alpha S)$-3-acetyl-7 $\alpha$-hydroxy-4-methyl-7-(propan-2-yl)-1,4,5,6,7,7 $\alpha$-hexahydro-2H-inden-2-one (63), $(4 S, 7 R, 7 \alpha S)$-3-acetyl-7 $\alpha$-hydroxy-7-methyl-4-(propan-2-yl)-1,4,5,6,7,7 -hexahydro-2H-inden-2-one (64) and (+)-(1S,2R,6S,9R)-1-hydroxy-2-(1-hydroxyethyl)-6-isopropyl-9-methylbicyclo[4.3.0]non-4-en-3-one (65) were detected in organic extract of $D$. divaricate. Biogenetically, the carbon skeletons of (60- 65) may be derived from the co-occurring cadinane skeleton by different ring contraction rearrangements. Compounds (6065) were inactive ( $\left.\mathrm{IC}_{50}>10 \mu \mathrm{g} / \mathrm{mL}\right)$ against several human cancer cell lines [55]. Cadinan-3-ene-1,5S-diol (31), 1-hydroxycadinan-3-en-5-one (66), cadinan-3-ene-1,5R-diol (67), cadinan-4(11)-ene-1,5-diol (68), cadinan4(11)-ene-1,5,12-triol (69), cadinan-1,4,5-triol (70) and 11-oxocadinan-4en-1-ol (71) were detected in organic extract of $D$. divaricate. Compounds (66- 71) were inactive against colon) against HCT-8, A549, Bel7402, MCF-7 and BGC-823 cell lines [56]. (+)-(1R,6S,9R)-1-hydroxyl-6-isopropyl-9-methylbicyclo[4.3.0]non-4-en3-one (72), (-)-(1S,6S,9R)-1-hydroxyl-6-isopropyl-9-methylbicyclo[4.3.0] non-4-en-3-one (73), (+)$(5 S, 6 R, 9 S)$-5-hydroxyl-6-isopropyl-9-methylbicyclo[4.3.0]non-1-en-3-one (74), 1-hydroxy-11-norcadinan-5en-4-one (75) were detected in organic extract of $D$. divaricate. Compounds (72- 75) were inactive $\left(\mathrm{IC}_{50}>10\right.$ $\mu \mathrm{g} / \mathrm{mL}$ ) against HCT-8, A549, Bel7402, MCF-7 and BGC-823 cell lines [57]. Germacra-1(10),4(15)-11-trien$5 S$-ol (76) was detected in $D$. divaricate [58]. (4E)-4-Methyl-10-methylidene-7-(prop-1-en-2-yl)cyclodec-4-en1-one and (7S)-(E)-7-1sopropenyl-4-methyl-10methylene-4-cyclodecan-1one (77), were detected in methanol extract of $D$. divaricate collected from Oshoro Bay (Japan) [59]. $\beta$-Elemene (39), cadalene (53), (-)- $\gamma$-cadinene (78) and (-)- $\delta$-cadinol (79) were detected in essential oils from the methanol extract of $D$. divaricate [60]. 


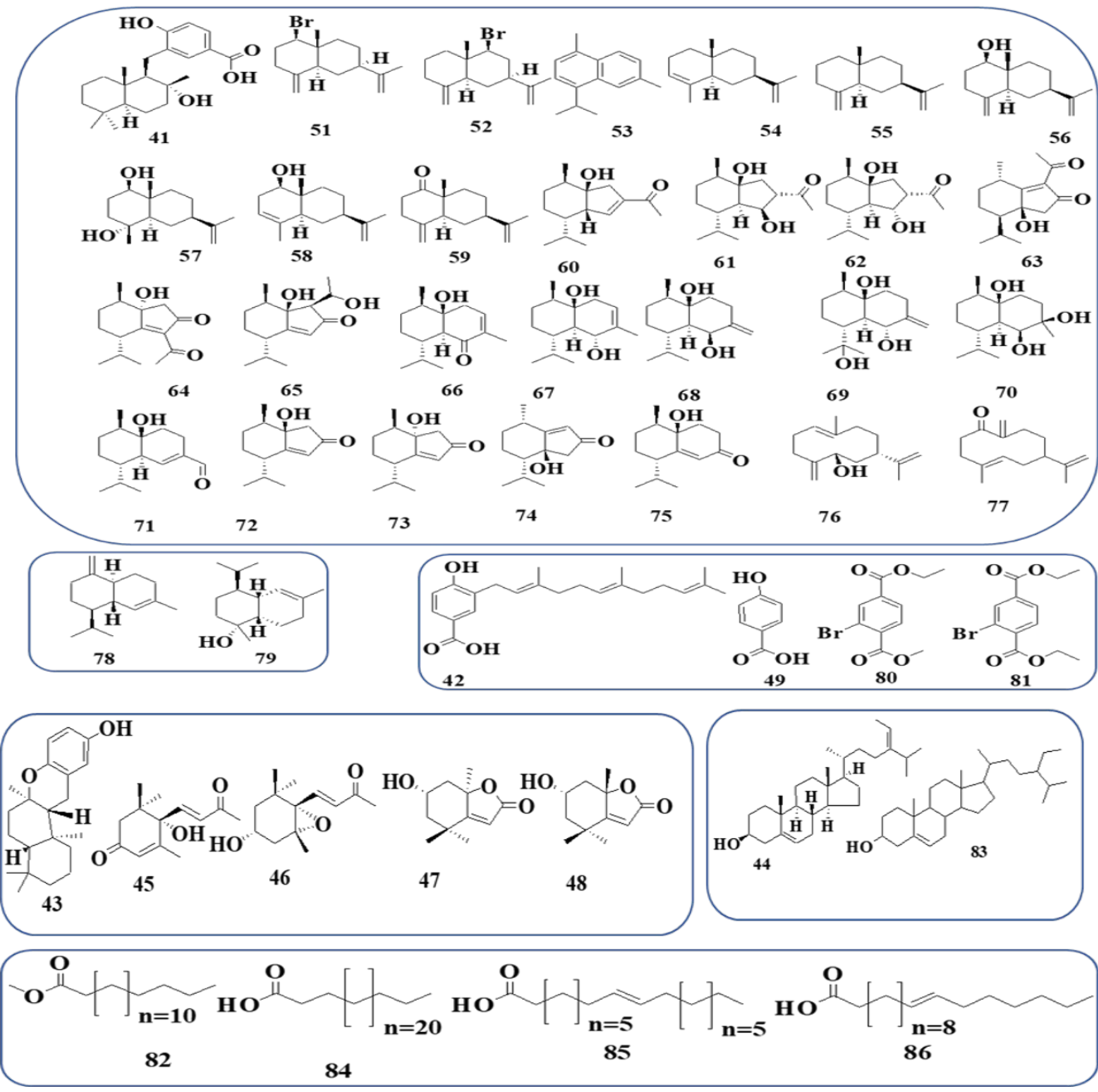

Fig. 2. Chemical structures of compounds 41-86. (41, 51, 79) sesquiterpenes, (42, 49, 80-81) aromatic derivative, $(43,45-48,50)$ terpenes, $(44,83)$ sterols, and $(82,84-86)$ fatty acid derivatives.

\section{Dictyopteris hoytii W. R. Taylor 1960}

$\mathrm{C}_{11}$ sulfur compounds from Dictyopteris sp. deterred amphipod feeding more strongly but had a minimal effect on sea urchin feeding [61]. Amphipods were not starved before being used in feeding assays. Amphipods consumed about 4 times more of the fresh thalli of $D$. hoytii (lacking the $\mathrm{C}_{11}$ sulfur compounds) than D. membranacea collected from North Carolina (USA). Organic extracts and water-soluble extracts from $D$. hoytii and D. membranacea were detected separately after incorporation into artificial foods at natural concentrations to calculate the feeding preference of A. longimana. It consumes foods with extracts from $D$. hoytii much more rapidly than foods with extracts from $D$. membranacea [62]. Fucosterol (44), ethyl methyl 2-bromobenzene 1,4-dioate (80), diethyl-2-bromobenzene 1,4-dioate (81) n-hexadecanoic acid, methyl ester (82), $\beta$-sitosterol (83), cerotic acid (84), n-octacos-9-enoic acid (85), and 11-eicosenoic acid (86) were detected 
in the methanolic extract of $D$. hoytii, collected from various locations along the coastal region of Raysut, Dhofar and Oman. The in vitro $\alpha$-glucosidase inhibition studies confirmed compound (85) to be the most active against $\alpha$-glucosidase enzyme ( $\left.\mathrm{IC}_{50}=30.5 \pm 0.41 \mu \mathrm{M}\right)$. Compounds (44) and (81) demonstrated good inhibition $\left(\mathrm{IC}_{50}=289.4 \pm 4.91\right.$, and $234.2 \pm 4.18 \mu \mathrm{M}$ respectively), while compounds (80), (83), and (84) showed moderate to low inhibition [63].

\section{Dictyopteris jamaicensis W. R. Taylor 1960}

Aqueous and organic extracts from D. jamaicensis, collected from the Gulf of Mexico, were tested for anti-trypanosomal activities against Trypanosoma cruzi at three different times. The aqueous extracts were active as an anti-trypanosomal after 7 days while the organic extract had no activity. None of the examined algal extracts showed toxicity against Artemia salina $\left(\mathrm{LC}_{50}>1000 \mu \mathrm{g} / \mathrm{mL}\right)$ [64]. The chloroform: methanol extracts of $D$. jamaicensis and $D$. justii, collected from costal water of Pureto Rico, were tested for antimicrobial activities against $B$. subtilus (mean inhibition zone $=0.5$ and $1 \mathrm{~mm}$, respectively) and $C$. albicans (mean inhibition zone $=2$ and $2.5 \mathrm{~mm}$ respectively), while those extracts did not have anti-microbial activity against $S$. aureus, $P$. aeruginosa, and E. coli [65].

\section{Dictyopteris jolyana E. C. Oliveira \& R. P. Furtado 1978}

Organic extracts of $D$. jolyana and $D$. delicatula, collected from the Brazilian coast, did not show any anti- (HSV-1) activity, any antiprotozoal activity or any antimicrobial activity against $S$. aureus, $P$. aeruginosa, E. faecalis, E. coli, and C. albicans [66]. Bis $(E)$-(3-oxo-undec-4-enyl) disulfide (87) and (E) -1- (5-methylthio3-oxo-undecyl) dissulfanilundec-4-en-3-one (88) were detected in $\mathrm{CH}_{2} \mathrm{Cl}_{2}-\mathrm{MeOH}(1: 1, \mathrm{v} / \mathrm{v})$ extract of $D$. jolyana, collected from the archipelago of Fernando de Noronha. Crude extract of D. jolyana produced considerable inhibition of platelet aggregation elicited by ADP, epinephrine, and partially reverse the first wave of ADP-induced aggregation. Fractions and isolated compounds considerably inhibited aggregation. Compound (87) produced lower antiplatelet activity with $\mathrm{IC}_{50}$ of $476.1 \pm 13.8 \mu \mathrm{M}$ for epinephrine and greater than $500 \mu \mathrm{M}$ for the other agonists [67].

\section{Dictyopteris justii J.V. Lamouroux 1809}

Two glucans, heterofucan, and fucoglucoxyloglucuronan were detected in D. justii (J.V. Lamouroux), collected from Maracajaú Beach (Brazil). Sugars were detected in all fractions (59.6 \% to $80.4 \%$ ) after proteolytic digestion, followed by acetone fractionation which degraded the contaminating proteins. Sulfate contents of the $D$. justii SPs were detected in lower value (3.9- $7.5 \%)$ than the polysaccharides of the $D$. delicatula $(14 \%-19 \%)$. Fucan (DJ-0.4v) had the best antioxidant activity and inhibited the crystallization of calcium oxalate, while Glucan (DJ-0.5v) was the second most potent inhibitor of the formation of oxalate crystals, as it stabilized the dehydrated oxalate crystals (less aggressive form), preventing the dehydrated oxalate crystals changes into the monohydrate crystals (more aggressive form). All sulfated polysaccharides inhibited the formation of calcium oxalate crystals [68]. The activity was reported for the sulfated polysaccharides extracted from D. justii (J.V. Lamouroux), collected at Maracajaú beach (Brazil). Three types of sulfated polysaccharides (two heterofucans and one glucan) were detected after proteolytic digestion, followed by acetone fractionation. The activated partial thromboplastin time activity of the $\mathrm{F} 0,4 \mathrm{v}$ fraction was like that of heparin [69]. (24R)-hydroperoxy-24-vinylcholesterol (89) and (24S)- hydroperoxy-24-vinylcholesterol (90), (Fig. 3) were reported as major sterols detected in acetone extract of the Brazilian D. justii. These compounds are considered cytotoxic mixture with anti-herbivory properties against the crab, $P$. transversus. The crude extract did not inhibit feeding, but the mixture of (89) and (90) epimers had a significant inhibition effect. The hydroperoxide can be considered as an oxidative product of fucosterol (44) [70,71]. 


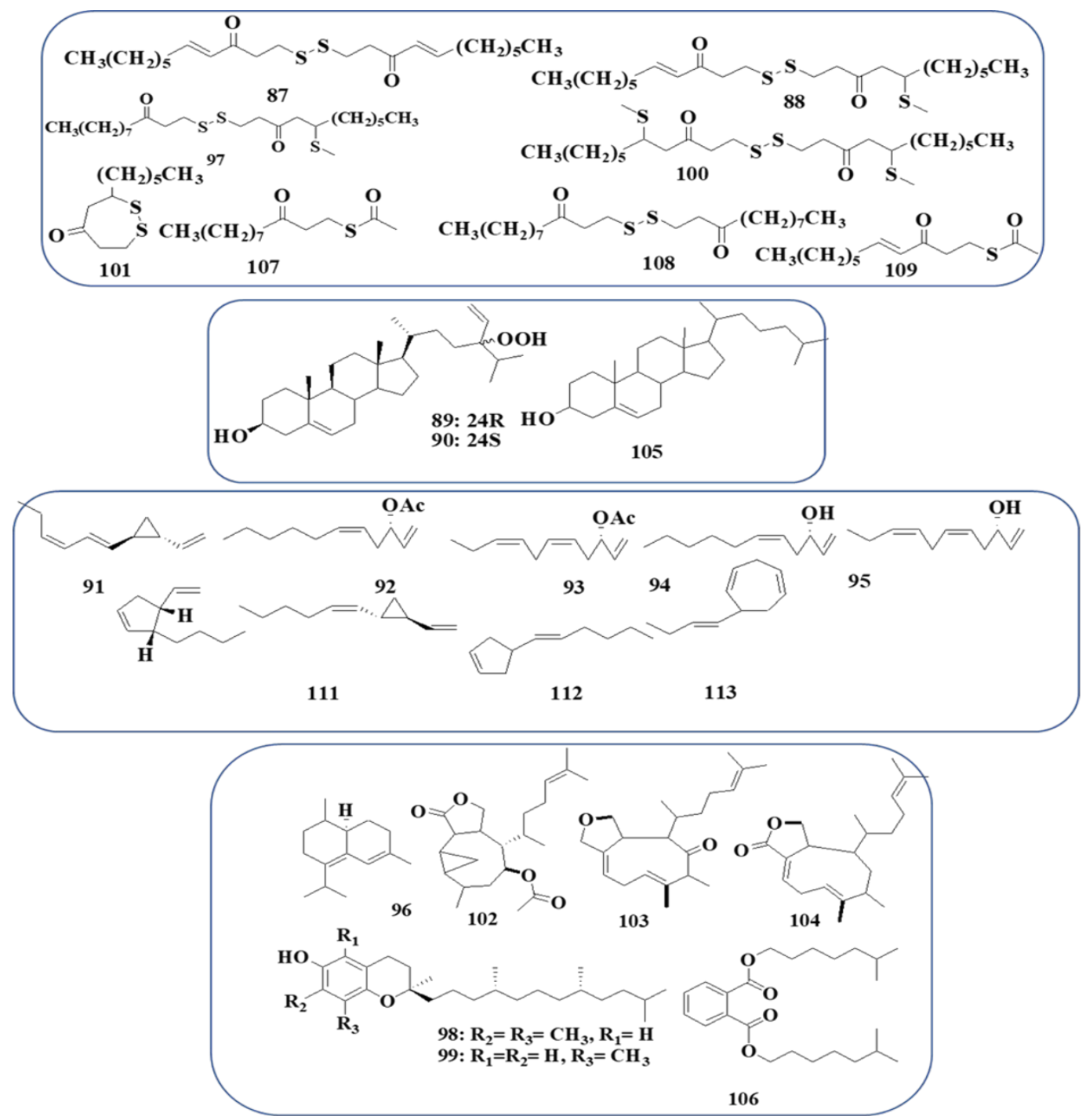

Fig. 3. Chemical structures of compounds 87-113. (87-88, 97, 100-101, 107-109) Sulfur containing derivatives, $(89-90,105)$ sterols, $(91-95,110-113)$ hydrocarbons, $(96,102-104)$ terpenes, $(98-99)$ vitamins, and (106) aromatic derivative.

\section{Dictyopteris latiuscula (Okamura) Okamura 1932}

2-Pentenal, hexanal, (2E)-hexenal, $(2 E, 4 E)$-heptadienal, nonanal, (2E,6Z )-nonadienal, $\beta$-cyclocitral, tridecanal, dictyopterene A (10), dictyopterene $\mathrm{C}^{\prime}(\mathbf{1 3})$, dictyopterne $\mathrm{D}^{\prime}$ (14) and dictyopterene $\mathrm{B}^{\prime}$ (91), pentadecanal, dictyoprolene (92), neodictyoprolene (93), dictyoprolenol (94), neodictyoprolenol (95), 1-penten3-ol, 2-pentenol, (3Z)-hexanol, hexanol, l-octen-3-ol, $\delta$-elemene and zonarene (96), were detected as volatile compounds identified in the essential oil of D. latiscula collected from Hiroshima Island (Japan) [72]. Both enantiomers of (3S)-(-)- and (3R)-(+)-Neodictyoprolenol [(3S,5Z,8Z)-(-)-1,5,8-unde-catrien- 3-ol] were successfully converted to the algal sex pheromone, $(1 S, 2 R)-(-)$-dictyopterene $\mathrm{B}$ and $(1 R, 2 S)-(+)$-dictyopterene $\mathrm{B}$ in high enantiomeric purities, respectively by the biomimetic reaction involving phosphorylation and elimination under a mild condition [73]. Biogenetic-type synthesis of ( \pm )-dictyopterene A (10) was achieved 
employing 1,cis-5-undecadien-3-ol postulated to be a biosynthetic intermediate, this synthesis means that transformation of dictyoprolene (92) into dictyopterene A (10) was formally achieved [74].

\section{Dictyopteris longifolia Papenfuss 1947}

Ethanolic extract from Southern African $D$. longifolia had antibacterial activity against food-associated bacteria B. subtilius, L. monocytogenes, L. mesenteroides, Micrococcus sp, S. auresa, A. lwoffii, Enterobacter sp., E. coli, P. fluorescens, and $S$. enteritidis (inhibition zone diameter ranging from 6 to $8 \mathrm{~mm}$ ) [75].

\section{Dictyopteris membranacea Batters 1902}

D. memberanacea is currently regarded as a synonym of D. polypodioides [3]. D. memberanacea collected from the western Libya coast was detected as antifungal against A. alternate, P. citrinum, A. flavus, A. ochraceus, E. nigrum, F. oxysporum, A. niger, and C. cladosporioides. The highest antifungal activity was recorded for cyclohexane extract. The maximum inhibitory action of cyclohexane extract was recorded against $F$. oxysporun and a moderate inhibitory action was recorded against $P$. citrinum, $A$. ochraceus, and $E$. nigrum [76]. Aqueous and organic extracts from $D$. membranacea, collected from the Tunisian coast exhibited high anti-inflammatory activity in carrageenan-induced rat paw edema assays and their effects are comparable to the reference drug acetylsalicylate lysine $(300 \mathrm{mg} / \mathrm{kg}$, applied intraperitoneally). D. membranacea extracts had inhibition percentages in the third hour of the assay by $65 \%$ at a dose of $100 \mathrm{mg} / \mathrm{kg}, 51 \%$ at a dose of $50 \mathrm{mg} / \mathrm{kg}$, and $49 \%$ at a dose of $100 \mathrm{mg} / \mathrm{kg}$ in aqueous, chloroform and ethyl acetate extracts, severally. Chloroform and ethyl acetate extracts exhibited 2,2-diphenyl-1-picrylhydrazyl radical scavenging activity $\left(\mathrm{IC}_{50}=0.089 \pm 0.01\right.$ and $0.11 \pm 0.02 \mathrm{mg} / \mathrm{mL}$, severally) equivalent to the activity of a powerful antioxidant standard trolox $\left(\mathrm{IC}_{50}=\right.$ $0.09 \pm 0.02 \mathrm{mg} / \mathrm{mL}$ ). Chloroform and ethyl acetate had reducing activity and the total phenol contents were calculated (84.96 and $60.96 \mathrm{GAE} \mathrm{mg/g} \mathrm{DW,} \mathrm{severally).} \mathrm{Organic} \mathrm{extracts} \mathrm{had} \mathrm{moderate} \mathrm{antimicrobial} \mathrm{activity}$ against $S$. aureus, $S$. epidermidis, M. luteus, C. albicans, C. krusei, C. dubliniensis, and C. kefyr at $10 \mathrm{mg}$ per disc, whereas the aqueous extract exhibited significant antibacterial activity against only $S$. aureus and $L$. monocytogenes [77]. Alginates detected in D. memberanacea, collected from Tunisia, have molecular weight with $58,000 \mathrm{~g} / \mathrm{mol}$ and exhibited gastroprotective effect $(83.41 \%$ at dose $50 \mathrm{mg} / \mathrm{kg}$ ) by inhibition of gastric lesions. The gastroprotective effect depends mainly on alginates uronic acid composition [78]. Tannin contents, total phenolic, and flavonoid were calculated in crude extract, semi-purified ethanol, acetone, and methanol/ $\mathrm{CH}_{2} \mathrm{Cl}_{2}$ fractions of Mediterranean D. membranacea, and detected for genotoxicity, antibacterial, antifungal, and antitubercular activities. The acetone fraction presented a source of tannin (130 $\mathrm{mg} \mathrm{CAE} / \mathrm{g} \mathrm{DW})$ and phenols (112 mg GAE/g DW), while the ethanol fraction showed the highest concentration of flavonoids (120 mg QE/g DW). Acetone and ethanol fractions had significant activities without any genotoxicity [79]. 3Allycyclobutane, bicyclo-(2,2,1)-heptadiene, 6-butyl-1,4-cycloheptadiene, thiophene-D3 and (E)-farnesene were detected in GC-MS analysis of D. membranacea, collected from Coast of Izmir (Turkey). The methanol, dichloromethane, hexane, chloroform, fractions, and volatile components of $D$. membranacea, were tested for antimicrobial activities against $S$. epidermidis, S. aureus, S. faecalis, B. subtilis, S. typhimurium, P. aeruginosa, E. cloacea, E. coli, and C. albicans. Extracts were inactive against $S$. faecalis, E. coli, and C. albicans, while methanolmethanolic extract was active against $S$. epidermidis and other extracts were also active (Inhibition zone $=7-16 \mathrm{~mm}$ ) [80]. 5-methylthio-1-(3-oxo-undecyl) disulfanylundecan-3-one (97) with other seven disulfides, along with 4-butyl-2,6-cycloheptadienone, $\gamma$-tocopherol (98), and $\delta$-tocopherol (99) were detected in organic extract of D. membranacea, collected at Gerolimenas Bay (Greece). Disulfide metabolites were examined for antibacterial activity against two resistant strains of $S$. aureus and one strain of $E$. coli and for anti-inflammatory activities. Disulfide metabolites were inactive as antibacterial while metabolite (97) was able to cause strong inhibition of $\mathrm{NO}$ production $\left(\mathrm{IC}_{50}=3.8 \mu \mathrm{M}\right)$ [81]. 5-methylthio-1-(3-oxo-undecyl) disulfanylundecan-3-one (97), bis(5-methylthio-3-oxo-undecyl) disulfide (100) and 3-hexyl-4,5dithiocycloheptanone (101) were detected in $\mathrm{CH}_{2} \mathrm{Cl}_{2}-\mathrm{MeOH}(1: 1, \mathrm{v} / \mathrm{v})$ extract of $D$. memberanacea, collected from Tinos island, Greece, inhibited activation of macrophages M1 by down regulating the production of proinflammatory cytokines such as TNFa, IL-6 and IL-12, suppressed the expression of iNOS, and enhanced expression of the macrophages M2 activation markers Arginase1 and MRC1 [82]. 4- Acetoxycrenulide (102), 18, 19-epoxyxenic-19-one-6,9,13-triene (103), dictyolactone (104), cholesterol (105) and diisooctyl phthalate (106) were detected in ethanol extract of D. memberanacea collected from the Mediterranean coast of Egypt 
(Fig. 3). Such ethanolic extract had free radical scavenging activity. Considerable inhibition of the rat paw edema produced by carrageenan was reported by chloroform and ethanol extracts and had potency of $84.8 \%$ and $84.5 \%$, respectively at dose $100 \mathrm{mg} / \mathrm{kg}$. Anti-microbial activity of petroleum ether, chloroform, ethyl acetate, and total ethanol extracts had antibacterial activities against $E$. coli, B. cereus, $S$. aureus, and $S$. pyogen and antifungal activities against, $A$. niger, S. cerevisea, M. phsaelia, F. oxysporium and C. albicans (Inhibition zone $=2$ to $10 \mathrm{~mm}$ ) with no activity against $M$. phsaelia [83]. The lipid metabolism of $D$. membranacea was detected using [1-14C] arachidonate, [1-14C] oleate, [1-14C] myristate, and [2-14C] acetate as precursors. On incubation with 16:0,18:1, and [2-14C] acetate were the main products formed by de novo synthesis and incorporated into polar lipids. With all the exogenous substrates used, diacylglyceryl hydroxymethyltrimethyl$\beta$-alanine was strongly labelled and the subsequent rapid turnover of radioactivity suggested a key role for this lipid in the redistribution of acyl chains and most likely also in the biosynthesis of the eukaryotic galactolipids produced in the absence of phosphatidylcholines. In the glycolipids a continuous accumulation of radioactivity was observed with all the substrates used. The labelling kinetics of molecular species of monogalactosyldiacylglycerol suggested the desaturation of 18:1 to 18:4 and of 20:4 (n-6) to 20:5 (n-3) acids on this lipid. Both phosphatidylglycerol and phosphatidylethanolamine were primary acceptors of de novo synthesized fatty acids and exogenous [1-14C] oleate, but no evidence exists for a further processing of acyl chains on these lipids. Triacylglycerols, although strongly labelled with all exogenous [1-14C] acids, was not labelled when [2-14C] acetate was used as a precursor indicating the flux of endogenous fatty acids to be different of that of exogenously supplied fatty acids [84].

\section{Dictyopteris muelleri (Sonder) Reinbold 1899}

The Phaeophyceae exhibited a fatty acid profile rich in the (18 and 20) carbon chain length PUFA. The main PUFA in the Phaeophyceae were 18:2(n-6), 18:3(n-3) and 18:4(n-3). Also, high proportions of the longchain polyunsaturated fatty acids were 20:4(n-6) and 20:5(n-3). Australian D. muelleri had a low percentage of PUFA in their fatty acid profiles. The ratio of n-6/n-3 PUFA was generally low in most Phaeophyceae species [85].

\section{Dictyopteris plagiogramma (Montagne) Vickers 1905}

3-hexyl-4,5-dithiacyclo-heptanone (101), S-(3-oxoundecyl) thioacetate (107), bis-(3-oxoundecyl) disulfide (108), S-(trans-3-oxoundec-4-enyl) thioacetate (109) were detected in the chloroform-methanol extract of D. plagiogramma, collected from Hawaii, (Fig. 3) [86]. Laminaran, fucose-containing polysaccharides, and alginic acid were detected in D. plagiogramma. The laminaran comprised G- and Mchains (ratio 3: 1). The polysaccharides contained slightly differing proportions of fucose, galactose, mannose, xylose, glucuronic acid residues, and half-ester sulphate. Non-reducing chain ends as well as the positions of glycosidic linkages to fucose, xylose and glucuronic acid are the same as previously reported for other fucanscontaining polysaccharides. Galactose and mannose occur mainly as trisubstituted residues with substitution at O-1, O-3, O-4 and at O-1, O-3, O-6, respectively [87].

\section{Dictyopteris polypodioides (A. P. De Candolle) J. V. Lamouroux 1809}

The polysaccharide detected in D. polypodioides, collected from the Mediterranean, exhibited antitumor activity against RPMI-7951 cell line. The principal polysaccharide of the D. polypodioides (about 12 $\%$ of the dry alga weight) was alginic acid. The content of water-soluble polysaccharides was low. The amount of fucoidan was less than $1 \%$ of the dry alga weight; of neutral polysaccharides, less than $0.25 \%$ [88]. The methanolic and ethyl acetate extracts of $D$. polypodioides collected from Chebba (Tunisia) showed antibacterial effect against E. coli, L. monocytogene, S. enteria, A. tumefaciens, P. aerigunosa, S. aureus, M. luteus, B. subtilis, B. amyloliquefaciens, A. niger, S. cerevisiae, F. oxysporum, and C. albicans. The methanolic and ethyl acetate extracts of $D$. polypodioides had an antibacterial effect against $S$. aureus and A. niger (mean inhibition zone $=27$ and $15 \mathrm{~mm}$ and $\mathrm{MIC}=50$ and $25 \mathrm{mg} / \mathrm{mL}$ severally) [89]. The essential oil of $D$. polypodioides, collected from the Mediterranean coast of Algeria and the volatile fraction, which was prepared from the crude ether extract, were subjected to GC/MS analysis. The GC/MS analysis of the volatile fraction and the essential oil revealed the presence of 72 and 70 compounds accounting for $86.4 \%$ and $80.6 \%$ of the total composition respectively. The main constituents in both oils were 3-hexyl-4,5-dithiacycloheptanone and dictyopterene. The 
antibacterial activitys of the volatile fraction and the essential oil were evaluated against $S$. aureus, A. tumefaciens, S. typhimurium, B. cereus, M. luteus, and E. coli. The essential oil had shown a high inhibitory effect against all the microorganisms tested as compared to the volatile fraction. S. aureus and A. tumefaciens were the most sensitive bacteria concerning the essential oil, $(\mathrm{MIC}=1519 \mu \mathrm{g} / \mathrm{mL})[90]$.

\section{Dictyopteris prolifera (Okamura) Okamura 1930}

Dictyoprolene (92) and neodictyoprolene (93) were detected in D. prolifera, collected from Wagu, Mai Prefecture (Japan) [91]. Dictyoprolenol (94) and neodictyoprolenol (95) which had been proposed as possible biosynthetic intermediates of the sex pheromones such as dictyopterene B (12), dictyopterene $\mathrm{C}^{\prime}$ (13), and dictyopterene D' (14), were detected in the essential oils of D. prolifera collected from Yoshimo Beach (Japan) together with the $\mathrm{C}_{11}$-related volatile compounds such as dictyoprolene (92) and neodictyoprolene (93) [72]. The isolation and structure elucidation (including the absolute stereochemistry) of (+)-dictyoprolene (92) a constituent of $D$. prolifera, together with the synthesis of (92) in optically active form indicated that (92) is the acetate of one of three undec-1-en-3-ols postulated to be key biosynthetic intermediates leading to various novel $\mathrm{C}_{11}$ hydrocarbons in Dictyopteris [92]. Cis-3-butyl-4-vinylcyclopentene (110), trans-1-[hexenyl]-2vinylcyclopropane (111), 4-[hexenyl]-cyclopentene (112) and 6-[butenyl]-cyclohepta-1,4-diene (113) were detected in the essential oils of fresh $D$. prolifera and $D$. undulata., collected from different coasts of Japan (Fig. 3). Compositions of $\mathrm{C}_{11}$ compounds and sesquiterpenes in the essential oils of the Dictyopteris in different growth localities were detected in D. prolifera and D. divaricate, collected around June from different coasts of Japan. (3E,5E)-Undeca-1,3,5-triene (5), (3E,5Z,8Z)-undeca-1,3,5,8-tetraene (7), dictyopterene A (10), dictyopterene B (12), dictyopterene $\mathrm{C}^{\prime}$ (13), dictyopterene $\mathrm{D}^{\prime}$ (14), cubenol (30), dictyoprolene (92), cis-3-butyl4-vinylcyclopentene (109), trans-1-[hexenyl]-2-vinylcyclopropane (110), 4-[hexenyl]-cyclopentene (111) and 6-[butenyl]-cyclohepta-1,4-diene (112) were mainly detected in $D$. prolifera while cubenol (30), $\beta$-elemene (39) and germacrene D (40) were detected as traces [33]. The ethanolic extract of edible D. prolifera, collected from all around Korea, evaluated for its inhibitory effects on $\alpha$-glucosidase. It showed effective inhibitory activity $\left(99.2 \%, \mathrm{IC}_{50}=16.66 \mu \mathrm{g} / \mathrm{mL}\right.$ ) compared to a positive control (Acarbose, $70.3 \%$ ), with no cytotoxicity on 3T3-L1) [93].

\section{Dictyopteris undulata Holmes 1896}

cis-3-Butyl-4-vinylcyclopentene, trans-2[(1Z)-hexenyl]-2-vinylcyclopropane, $\quad(1,3 E, 5 Z \quad, 8 Z \quad)$ undecatetraene, undecane, 6-[(1E)-butenyl]-cyclohepta-1,4-diene, 2-pentenal, hexanal, $(2 E)$-hexenal, $(2 E, 4 E)$ heptadienal, nonanal, $(2 E, 6 Z)$-nonadienal, $\beta$-cyclocitral,tridecanal, pentadecanal, 1-penten-3-ol, 2-pentenol, (3Z)-hexenol, 1-O cten-3-ol, $\gamma$ - selinene, $\beta$-caryophyllene, $\alpha$-cadinene, $\beta$-copaene, dictyopterene A (10), dictyopterene $\mathrm{C}^{\prime}$ (13), dictyopterne $\mathrm{D}^{\prime}$ (14), cubenol (30), epicubenol (32), $\alpha$ - cubebene (36), $\beta$-elemene (39), Germacrene D (40), $\alpha$-dictyoprolenol (58), dictyopterene B' (91), dictyoprolene (92), neodictyoprolene (93), neodictyoprolenol (95), zonarene (96), and 4-[hexenyl]-cyclopentene (112) were detected by GC-MS of volatile compounds of unidentified species of Dictyopteris collected from beach around Susa in Yamaguchi prefecture, Japan while neodictyoprolenol (95) D. undulata. Dictyoprolenol (94) and neodictyoprolenol (95) considered as biosynthetic intermediates of the sex pheromones such as dictyopterene $B(\mathbf{1 2})$, dictyopterene $C^{\prime}(\mathbf{1 3})$, and dictyopterene $\mathrm{D}^{\prime}$ (14) detected in the essential oils together with the $\mathrm{C}_{11}$-related volatile compounds [72]. Ethanolic extract of D. undulata, collected from Jeju Island (Korea), showed anticancer activity in SW480 cell line, $\left(\mathrm{IC}_{50}=40 \mu \mathrm{g} / \mathrm{mL}\right)$. Treatment by ethanolic extract for $24 \mathrm{~h}$ induced the expression of both rabbit recombinant monoclonal phospho-PERK, phospho-IRE1 antibody and the levels of both phosphoproteins returned to basal values. Ethanolic extract induced other hallmarks of the endoplasmic reticulum stress responses such as cleavage of activating transcription factor 6 and activation of caspase-12 [94]. (24S)Saringosterol (114), (24R)-saringosterol (115), dictyopterisin A- J (116- 125) were detected in $95 \%$ aqueous ethanolic extract of D. undulata, collected from the Zhanjiang coastline (China). Dictyopterisins A- J (116125) including three pairs of C-24 epimers, dictyopterisins (B-C), (F-G), and (I-J), were detected in D. undulata Holmes, collected from southeastern Chinese coastline (Fig. 4), The mixture of dictyopterisin D (119), dictyopterisin E (120) and dictyopterisin I (124) exhibited promising PTP1B inhibitory activities with IC $_{50}$ values of 1.88 and $3.47 \mu \mathrm{M}$, severally, comparable to the positive control of oleanolic acid $\left(\mathrm{IC}_{50}=2.78 \mu \mathrm{M}\right)$. Additionally, the mixture of dictyopterisin D (119), dictyopterisin E (120) and dictyopterisins F- J (121- 125) 
displayed considerable anticancer activities against (HL-60, $\mathrm{IC}_{50}$ from 1.02 to $\left.2.70 \mu \mathrm{M}\right)$ and $\left(\mathrm{A}-549, \mathrm{IC}_{50}\right.$ from 1.35 to $2.85 \mu \mathrm{M}$ ) (Fig. 4) [95]. Saringosterol (114) and (115) are LXR $\beta$ agonist whilethe most potent compounds in stimulating the transcriptional activities of LXR $\alpha$ by $(3.81 \pm 0.15)$-fold and LXR $\beta$ by $(14.40 \pm 1.10)$-fold were detected. (24S)-Saringosterol (114) was more potent than (24R)-saringosterol (24R)-saringosterol (115) in LXR $\beta$-mediated transactivation $((3.50 \pm 0.17)$-fold vs $(1.63 \pm 0.12)$-fold $)$ compared with the control. Consistently, (24S)-Saringosterol (114), induced higher expression levels of (LXR) target genes including key players in reverse cholesterol transport in six cell lines. (24S)-Saringosterol (114), acted as a selective LXR $\beta$ agonist and is a potent natural cholesterol-lowering contributed to the well-known anti-atherosclerotic function [96]. Dictyoptesterols A-C (126-128) are cholestane-type sterols bearing an unusual $\Delta^{22}-24$-oxo side chain and

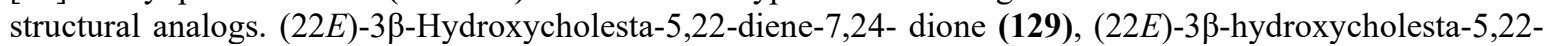
diene-24-one (130), 3 $\beta$-hydroxycholesta-5-ene-7,24-dione (131), 24-oxocholesterol (132) and 7-oxocholesterol (133) were detected in ethanol extract of $D$. undulata Holmes, collected from South China Sea. All the isolates were evaluated in vitro for their potential to inhibit PTP1B activity. Compounds (126-130) exhibited different levels of PTP1B inhibitory activities $\left(\mathrm{IC}_{50}\right.$ from $3.03 \pm 0.76$ to $\left.15.01 \pm 2.88 \mu \mathrm{M}\right)$. Compounds (128) and (129) showed promising inhibitory effects towards PTP1B $\left(\mathrm{IC}_{50}=3.03 \pm 0.76\right.$ and $3.72 \pm 0.40 \mu \mathrm{M}$, severally) when compared to the positive control oleanolic acid $\left(\mathrm{IC}_{50}=2.83 \pm 0.39 \mu \mathrm{M}\right)$ [97]. 7-oxocholesterol (133) is accumulated in the liver after cholesterol feeding, formed from cholesterol during lipid peroxidation [98]. 7oxocholesterol (133) inhibited eNOS and cPLA2 activation by altering a $\mathrm{Ca}^{2+}$-independent upstream step of PI3K and ERK1/2 pathways, whereas LPC desensitized eNOS by interfering with receptor-activated signaling pathways. 7-Oxocholesterol (133) and LPC generate signals which crosstalk with heterologous receptors, effects that could appear at the early stage of atherosclerosis [99]. Chromazonarol (43), zonarenone (134), zonarol (135), isozonarol (136), yahazunol (137), isochromazonarol (138), zonaroic acid (139), and 2-[(2E,6E)3,7,11-trimethyldodeca-2,6,10-trien-1-yl]benzene-1,4-diol (140) were detected in methanol extract of $D$. undulata, The algicidal activity of the isolated compounds was reported against the four representative red tide microalgal species, Heterosigma akashiwo (Raphidophyte), Chattonella marina (Raphidophyte), Chattonella antiqua (Raphidophyte) and Heterocapsa circularisquama (dinoflagellate) at a concentration of $1 \mathrm{mg} / \mathrm{mL}$. All the bicyclic compounds (134- 140), excepting zonaroic acid (139), showed a high level of algicidal activity against $H$. akashiwo and $H$. circularisquama, among which yahazunol (136) had the highest activity. Yahazunol (136) also showed high activity against $C$. marina, while the other bicyclic terpenoids were mostly inactive [100]. Zonarol (135) act as a neuroprotective pro-electrophilic compound which activates the neuroprotective Nrf2-ARE pathway, induces phase-2 enzymes and protects neuronal cells from oxidative stress. [101] Chromazonarol (43), isozonarol (136), zonaroic acid (139), isozonaroic acid (141), and isozonarone (142) were detected in methanol extract of D. undulata, collected from Chichi-Jima Island and Haha-jima Island (Japan), (Fig. 4). All five compounds were evaluated for DPPH radical scavenging activity. The intensity of the 2,2diphenyl-1-picrylhydrazyl (DPPH) radical scavenging activity was highest for isozonarol (136) which has a hydroquinone structure, and it's $\mathrm{EC}_{50}$ values $(71 \mu \mathrm{M})$ were comparable to the positive control ( $\alpha$-tocopherol). The activity was weakened with chromazonarol (43) and isozonarone (142) without the para-hydroquinone structure. The precursor of these sesquiterpenoids biosynthesis is farnesyl diphosphate. Since the stereochemistry of the cyclization reaction product of farnesyl diphosphate is controlled by the folding forms on the substrate surface of the cyclase, it is conceivable that the enantiomer is formed by a single enzyme [102]. Cyclozonarone (143) is a sesquiterpene-substituted benzoquinone derivative that was detected in methanol extract of $D$. undulata, collected from the Isoyake area of Japan. Cyclozonarone (143) showed potent feedingdeterrent activity [103]. Several piscicidal compounds including chromazonarol (43), isochromazonarol (138) and chromenol (144) were detected in Japanese D. undulata [104]. The total synthesis of yahazunol (137) and chromazonarol (43) was achieved starting from p-toluenesulfonyl hydrazide. The key steps were a palladiumcatalyzed tandem carbene migratory insertion of an aryl iodide and a drimanalhydrazone, a highly regionselective enol reduction, an oxa-Stork-Danheiser transposition reaction, an electrocyclization of a conjugated tetraenone, and a redox reaction of dimethoxybenzenes [105]. While the total synthesis of yahazunol (137), isozonarone (142), and zonarone (138) were starting from (+)-albicanic acid. The key step was the coupling of the sesquiterpene part with the lithiated hydroquinone ethers led to sesquiterpene arenes, which were further modified to the target molecules. Stereoselective epoxidation followed by the regioselective opening of the oxirane ring yielded yahazunol (137) [106]. D. undulate have showed potential anti-bacterial activity against $S$. 
mutans, S. sobrinus, S. anginosus, S. aureus, and S. epidermis. S. anginosus, S. aureus, and S. epidermis compared to chemical antibacterial agents like streptomycin against oral pathogens [107].

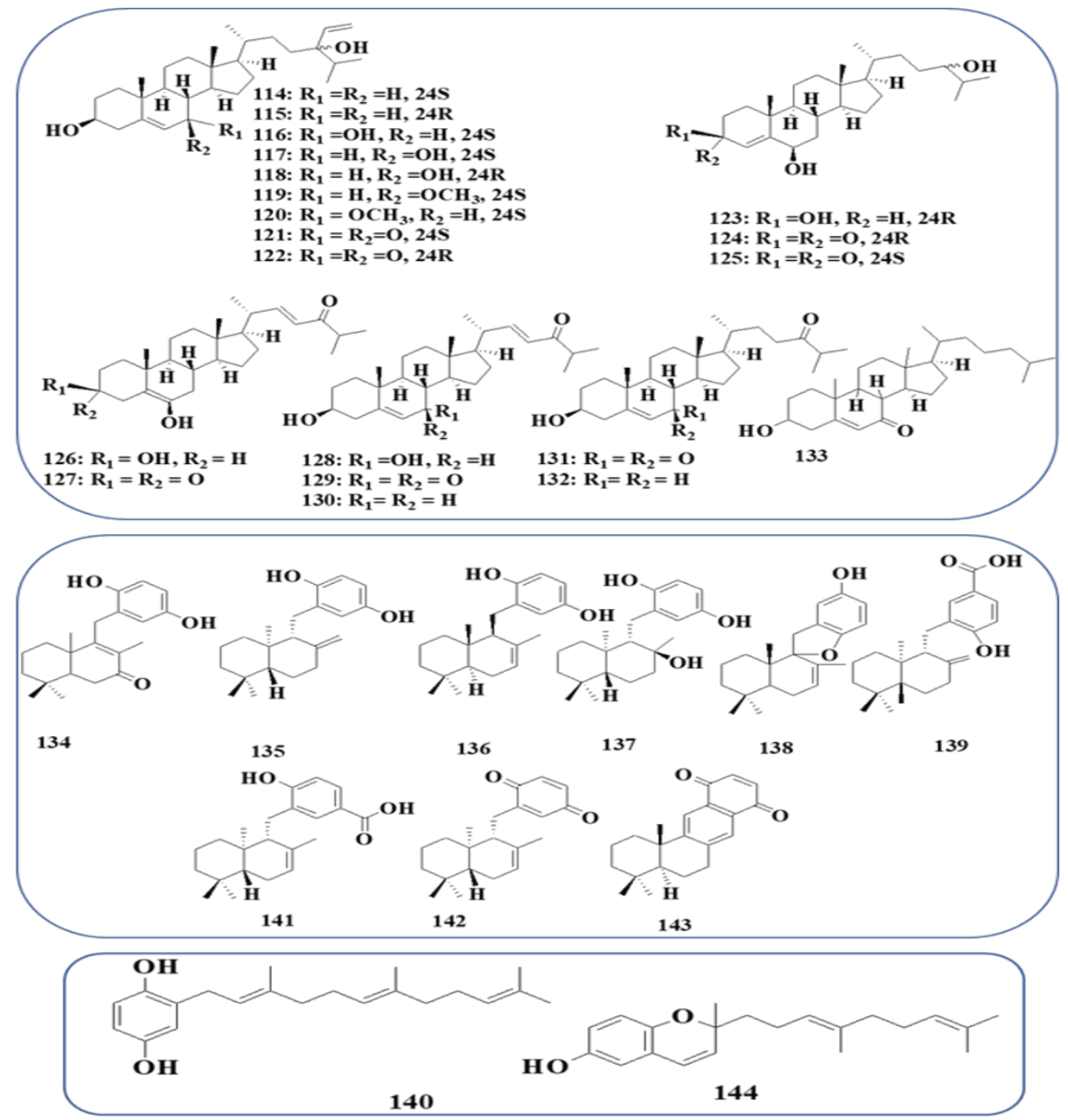

Fig. 4. Chemical structures of compounds 114-144, (114-133) sterols, (134-139, 141-143) Sesquiterpenes, and (140-144) phenolic derivative).

\section{Dictyopteris zonarioides Farlow 1899}

$D$. zonarioides is currently regarded as a synonym of $D$. undulata [3]. The major hydrocarbon component $D$. zonarioides, collected from Mexico, Zonarene (96) has been isolated and identified as the first $\mathrm{C}_{15} \mathrm{H}_{24}$ conjugated diene sesquiterpene of the cadanane type [108]. Isozonarol (136) and zonarol (135) isomeric $\mathrm{C}_{21}$ hydroquinones have been obtained from methanol extract of $D$. zonarioides, collected in the Pacific Ocean near the Gulf of California, Both (135) and (136) are moderate fungitoxic hydroquinones toward $P$. cinnamomic, R. solani, S. sclerotiorum, and S. rolfsii [109]. Zonarol (135) prevents inflammation and apoptosis in dextran sulfate sodium-induced mice ulcerative colitis [110]. 


\section{Critical assessment}

Dictyopteris is considered a functional food in many marine cultures in particular D. divaricata and D. prolifera. Several published types of research confuse genus Dictyopteris with other members from the same family due to the semi-vegetarianism. No comprehensive work has been published on the chemical characterization of many Dictyopteris spp. Since Dictyopteris spp. are known to biosynthesize a broad array of specific compounds such as $\mathrm{C}_{11}$ hydrocarbons, sterols, sesquiterpenes, and sulfur containing derivatives, no comprehensive work has been published on the chemical structure of sulphated polysaccharides. $\mathrm{C}_{11}$ hydrocarbons, sterols, sesquiterpenes, and sulfur containing derivatives were the most distributed phyto chemicals within Dictyopteris spp._ Published work since 1948 on genus Dictyopteris focuses on taxonomic and distribution of genus Dictyopteris. Fifteen species of genus Dictyopteris, representing about $44.11 \%$ of the current species, were taxonomically accepted and investigated for their chemical profiling with two synonyms, while, twelve species, demonstrating approximately $\mathbf{3 5 . 2 9} \%$ of the current species, were accepted taxonomically and tested for their pharmacological activities. Most pharmacological activities of genus Dictyopteris were attributed to its polar fractions. Thirty extracts were investigated for their pharmacological activities, of which most of them were detected as crude extracts without identification of their phytochemicals, that responsible for their pharmacological activities. Fucoidans and alginate were isolated from aqueous extracts without elucidation of their chemical structure. $25 \%$ of the detected phytochemicals are sterols, investigated for their in vivo antiproliferative and PTP1B inhibitor while no antiproliferative detected for sesquiterpenes which represent $40 \%$ of total reported phytochemicals. Sulfur containing derivatives (6\%) investigated as potent anti-inflammatory. The presence of phenolic principles explains antioxidant activities of six extracts, representing $20 \%$ of the studied extracts. four extracts, representing $13.33 \%$ of studied extracts, and seventeen identified constituents, representing $14.4 \%$ of the detected phytochemicals, revealed in vivo antiproliferative potentials towards a panel of cell lines. Metabolites including $\mathrm{C}_{11}$-hydrocarbons and sulfur compounds are considered the chemo phenetic markers of genus Dictyopteris.

\section{Future perspective}

Only two species, D. acrostichoides and D. memberanacea were detected in the Red sea environment and all were investigated for their phytochemical and pharmacological diversity. In spite of the folk use of Dictyopteris, all over the world, the knowledge about its phytochemical and pharmacological potentials is still underexplored. Analysis of the reported data regarding its phytoconstituents has shown some large gaps in our perception of the biological activities and health benefits of Dictyopteris. The roles performed by each metabolite also need to be investigated. Existing biological research on several Dictyopteris species is particularly limited to their total extracts or fractions, while the isolated components have received much less interest. Further studies should be comprehensively done to identify metabolites and their actual contribution to the medicinal properties of Dictyopteris, in addition to the mechanisms and their possible synergistic interactions. This would guide the safe and effective application of Dictyopteris species in modern phytotherapy. From a medicinal viewpoint, the antiproliferative potential of genus Dictyopteris represents an indispensable future research theme. Many sesquiterpenes were detected as inactive antiproliferative without detection of pharmacological potential of these sesquiterpenes. Many studies have shown the cytotoxic properties of Dictyopteris species. This mechanism of action should be considered in future research to best appreciate these potentials. The anti-microbial potential is another considerable challenge because the current reported antimicrobial data are mostly restricted to crude extracts and fractions of Dictyopteris species. Further investigation required in Dictyopteris nanoparticle applications. Investigating bioactive metabolites obtained from the genus Dictyopteris should include more structure-activity relationship studies, as well as illuminating their possible mechanisms of actions. Discovering the cellular and molecular features of the biological activities of Dictyopteris metabolites will be valuable in designing new bioactive compounds. Synthetic analogs of bioactive metabolites of genus Dictyopteris should be developed, focusing on improving the efficacy, safety, and increasing its economic production as a food source with a further investigation as a natural source of drugs. 


\section{Conclusion}

The publication rate for the genus Dictyopteris (Fig. 5) increased during the last five years with significant variation in its phytochemical and clinical application. Dictyopteris has 34 species accepted taxonomically based on literature. Eighteen species were detected for their phytochemical and clinical applications which represented $47.05 \%$ of species accepted taxonomically. the most tested species were $D$. divaricate, D. membranacea, D. prolifera, and $D$. undulata. This review focused on updated information about Dictyopteris according to phycological rules with chemical and pharmacological diversity of genus Dictyopteris and its metabolities. Most of the detected compounds are alicyclic $\mathrm{C}_{11}$ hydrocarbons (Fig. 6), nonfunctionalized acyclic, and unsaturated acyclic compounds. Alginates detected in Dictyopteris acted as a gastroprotective drug. Sesquiterpenes were the major phytochemical class with alcohols, sulfides, hydrocarbons, isoprenoids, and many fatty acid derivatives (Fig. 6, Table 1 and 2). Genus Dictyopteris was detected as a valuable source for developing novel natural products for clinical application. The most detected fatty acids were palmitic acid and PUFA (n-3 and n-6) in different percentages depends on species and time of collection. Fucosterol was detected as a major sterol with genus diversity. Several biological and pharmacological uses of genus Dictyopteris have been reported owing to its antioxidant activities (Fig. 6, Table 1 and 2). The most pharmacological activities of genus Dictyopteris were reported as antimicrobial, anti-proliferative, antioxidant, anti-inflammatory, antiherbivory, cardioprotective, neuroprotective, PTPIB inhibitor, and gastroprotective activities. Further investigations must apply to the bioactive metabolites obtained from Dictyopteris with more structure-activity relationships studies as well as possible mechanisms of actions of clinical application with the synthesis of those phytochemicals in economic yield.

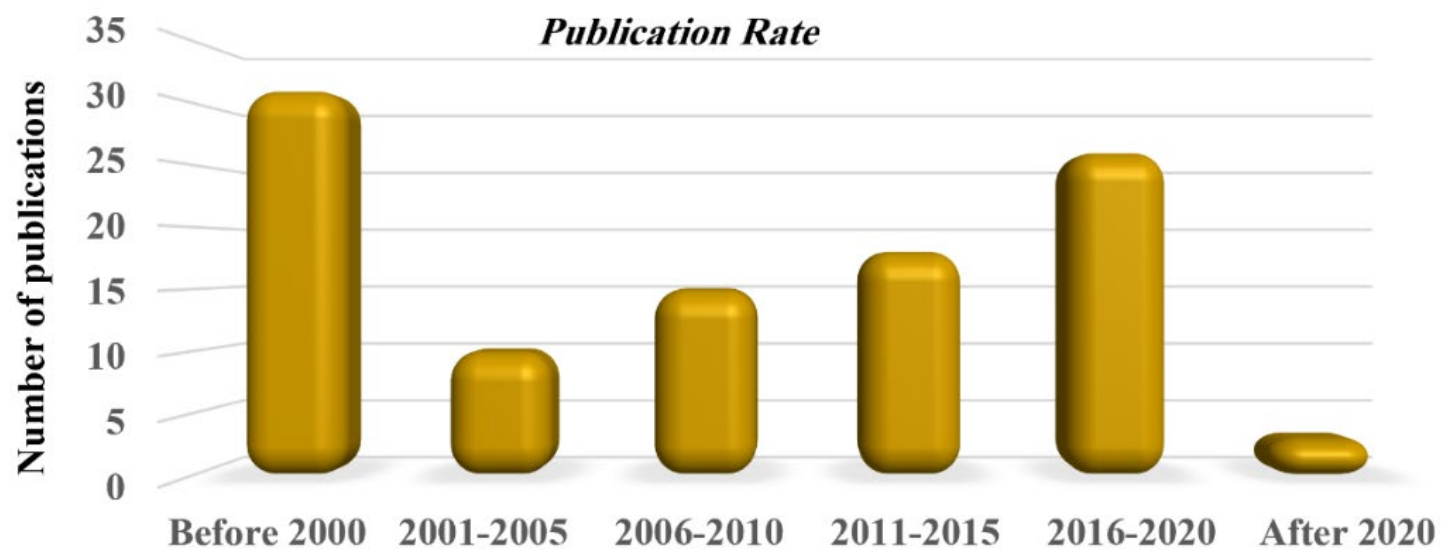

Fig. 5. Publication profile of genus Dictyopteris.
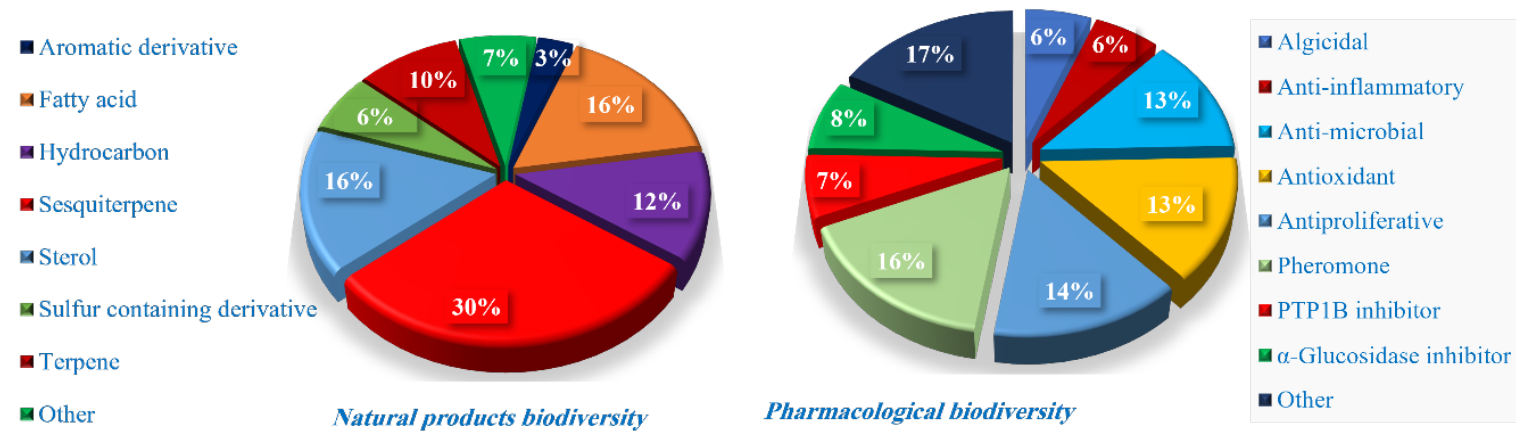

Fig. 6. Natural products and pharmacological biodiversity of genus Dictyopteris. 
Table 1: Biological assays related to therapeutic potential of Dictyopteris compounds.

\begin{tabular}{|c|c|c|c|c|}
\hline $\begin{array}{c}\text { Compound } \\
\text { number }\end{array}$ & Species & Solvent & Activity & References \\
\hline 1 & D. acrostichoides & Organic & Pheromone & {$[6]$} \\
\hline 2 & D. acrostichoides & Organic & Pheromone & {$[6]$} \\
\hline 3 & D. acrostichoides & Organic & Pheromone & {$[6]$} \\
\hline 4 & D. acrostichoides & Organic & Pheromone & {$[6]$} \\
\hline 5 & $\begin{array}{l}\text { D. acrostichoides } \\
\text { D. prolifera }\end{array}$ & Organic & Pheromone & {$[6,33]$} \\
\hline 6 & D. acrostichoides & Organic & Pheromone & {$[6]$} \\
\hline 7 & $\begin{array}{l}\text { D. acrostichoides } \\
\text { D. prolifera }\end{array}$ & Organic & Pheromone & {$[6,33]$} \\
\hline 8 & D. acrostichoides & Organic & Pheromone & {$[6]$} \\
\hline 9 & D. acrostichoides & Organic & Pheromone & {$[6]$} \\
\hline 10 & $\begin{array}{l}\text { D. australis } \\
\text { D. latiscula } \\
\text { D. plagiogramma } \\
\text { D. prolifera }\end{array}$ & Organic & Pheromone & {$[9,33,72]$} \\
\hline 11 & $\begin{array}{c}\text { D. australis } \\
\text { D. plagiogramma }\end{array}$ & Organic & Pheromone & [9] \\
\hline 12 & $\begin{array}{l}\text { D. australis } \\
\text { D. plagiogramma } \\
\text { D. prolifera }\end{array}$ & Organic & Pheromone & {$[10,11,33]$} \\
\hline 13 & $\begin{array}{l}\text { D. australis } \\
\text { D. latiscula } \\
\text { D. plagiogramma } \\
\text { D. prolifera }\end{array}$ & Organic & Pheromone & {$[10,11,33,72]$} \\
\hline 14 & $\begin{array}{l}\text { D. australis } \\
\text { D. latiscula } \\
\text { D. plagiogramma } \\
\text { D. prolifera }\end{array}$ & Organic & Pheromone & {$[10,11,33,72]$} \\
\hline 15 & $\begin{array}{c}\text { D. australis } \\
\text { D. plagiogramma }\end{array}$ & Organic & - & {$[10,11]$} \\
\hline 16 & $\begin{array}{c}\text { D. australis } \\
\text { D. plagiogramma }\end{array}$ & Organic & - & {$[10,11]$} \\
\hline 17 & $\begin{array}{c}\text { D. australis } \\
\text { D. plagiogramma }\end{array}$ & Organic & - & {$[13]$} \\
\hline 18 & $\begin{array}{c}\text { D. australis } \\
\text { D. plagiogramma }\end{array}$ & Organic & - & {$[13]$} \\
\hline 19 & D. australis & $\mathrm{EtOH}$ & - & {$[16]$} \\
\hline 20 & D. australis & $\mathrm{EtOH}$ & - & {$[16]$} \\
\hline 21 & $\begin{array}{l}\text { D. delicatula } \\
\text { D. divaricata }\end{array}$ & $\mathrm{EtOH}$ & - & {$[21]$} \\
\hline 22 & $\begin{array}{l}\text { D. delicatula } \\
\text { D. divaricata }\end{array}$ & $\mathrm{CHCl}_{3}-\mathrm{MeOH}(1: 1, \mathrm{v} / \mathrm{v})$ & - & {$[21,30]$} \\
\hline 23 & $\begin{array}{l}\text { D. delicatula } \\
\text { D. divaricata }\end{array}$ & $\mathrm{CHCl}_{3}-\mathrm{MeOH}(1: 1, \mathrm{v} / \mathrm{v})$ & - & {$[21,30]$} \\
\hline 24 & D. delicatula & $\mathrm{MeOH}$ & Antioxidant & {$[23]$} \\
\hline
\end{tabular}




\begin{tabular}{|c|c|c|c|c|}
\hline 25 & D. delicatula & $\mathrm{MeOH}$ & Antioxidant & [23] \\
\hline 26 & D. delicatula & $\mathrm{MeOH}$ & Antioxidant & [23] \\
\hline 27 & D. divaricata & $\mathrm{CHCl}_{3}-\mathrm{MeOH}(1: 1, \mathrm{v} / \mathrm{v})$ & - & [30] \\
\hline 28 & D. divaricata & $\mathrm{CHCl}_{3}-\mathrm{MeOH}(1: 1, \mathrm{v} / \mathrm{v})$ & - & [30] \\
\hline 29 & D. divaricata & $\mathrm{CHCl}_{3}-\mathrm{MeOH}(1: 1, \mathrm{v} / \mathrm{v})$ & - & {$[30]$} \\
\hline 30 & $\begin{array}{l}\text { D. divaricata } \\
\text { D. prolifera }\end{array}$ & $\mathrm{CHCl}_{3}-\mathrm{MeOH}(1: 1, \mathrm{v} / \mathrm{v})$ & - & {$[30,33,72]$} \\
\hline 31 & D. divaricata & $\mathrm{CHCl}_{3}-\mathrm{MeOH}(1: 1, \mathrm{v} / \mathrm{v})$ & - & {$[30]$} \\
\hline 32 & D. divaricata & $\mathrm{MeOH}$ & - & {$[31,72]$} \\
\hline 33 & D. divaricata & $\mathrm{MeOH}$ & - & [31] \\
\hline 34 & D. divaricata & $\mathrm{MeOH}$ & - & [31] \\
\hline 35 & D. divaricata & $\mathrm{MeOH}$ & - & [31] \\
\hline 36 & D. divaricata & $\mathrm{MeOH}$ & - & {$[31,72]$} \\
\hline 37 & D. divaricata & $\mathrm{MeOH}$ & - & [31] \\
\hline 38 & D. divaricata & $\mathrm{MeOH}$ & - & [31] \\
\hline 39 & $\begin{array}{l}\text { D. divaricata } \\
\text { D. prolifera }\end{array}$ & - & Antiproliferative & {$[33,72]$} \\
\hline 40 & $\begin{array}{l}\text { D. divaricata } \\
\text { D. prolifera }\end{array}$ & - & - & {$[33,72]$} \\
\hline 41 & D. divaricata & $\mathrm{EtOH}$ & - & [37] \\
\hline 42 & D. divaricata & EtOH & - & [37] \\
\hline 43 & $\begin{array}{l}\text { D. divaricata } \\
\text { D. undulata }\end{array}$ & $\begin{array}{l}\text { EtOH } \\
\mathrm{MeOH}\end{array}$ & $\begin{array}{c}\text { Algicidal } \\
\text { Antioxidant }\end{array}$ & {$[37,100,102]$} \\
\hline 44 & $\begin{array}{l}\text { D. divaricata } \\
\text { D. hoytii }\end{array}$ & $\mathrm{EtOH}$ & $\begin{array}{c}\text { Antiproliferative } \\
\text { Antiadipogenic } \\
\alpha \text {-Glucosidase } \\
\text { inhibitor }\end{array}$ & [37] \\
\hline 45 & D. divaricata & $\mathrm{EtOH}$ & - & [37] \\
\hline 46 & D. divaricata & $\mathrm{EtOH}$ & - & {$[37]$} \\
\hline 47 & D. divaricata & $\mathrm{EtOH}$ & $\begin{array}{l}\text { Photoprotective } \\
\text { Antiproliferative }\end{array}$ & [37] \\
\hline 48 & D. divaricata & $\mathrm{EtOH}$ & Antiproliferative & [37] \\
\hline 49 & D. divaricata & $\mathrm{EtOH}$ & $\begin{array}{l}\text { Antimicrobial } \\
\text { Hypoglycemic }\end{array}$ & [42] \\
\hline 50 & D. divaricata & $\mathrm{CHCl}_{3}-\mathrm{MeOH}(1: 1, \mathrm{v} / \mathrm{v})$ & - & [52] \\
\hline 51 & D. divaricata & $\mathrm{CHCl}_{3}-\mathrm{MeOH}(1: 1, \mathrm{v} / \mathrm{v})$ & - & [53] \\
\hline 52 & D. divaricata & $\mathrm{CHCl}_{3}-\mathrm{MeOH}(1: 1, \mathrm{v} / \mathrm{v})$ & - & [53] \\
\hline 53 & D. divaricata & $\mathrm{CHCl}_{3}-\mathrm{MeOH}(1: 1, \mathrm{v} / \mathrm{v})$ & - & [53] \\
\hline 54 & D. divaricata & $\mathrm{CHCl}_{3}-\mathrm{MeOH}(1: 1, \mathrm{v} / \mathrm{v})$ & - & [53] \\
\hline 55 & D. divaricata & $\mathrm{CHCl}_{3}-\mathrm{MeOH}(1: 1, \mathrm{v} / \mathrm{v})$ & - & [53] \\
\hline 56 & D. divaricata & $\mathrm{CHCl}_{3}-\mathrm{MeOH}(1: 1, \mathrm{v} / \mathrm{v})$ & - & [53] \\
\hline 57 & D. divaricata & $\mathrm{CHCl}_{3}-\mathrm{MeOH}(1: 1, \mathrm{v} / \mathrm{v})$ & - & [53] \\
\hline
\end{tabular}




\begin{tabular}{|c|c|c|c|c|}
\hline 58 & D. divaricata & Organic & - & {$[54,72]$} \\
\hline 59 & D. divaricata & Organic & - & {$[54]$} \\
\hline 60 & D. divaricata & Organic & - & {$[55]$} \\
\hline 61 & D. divaricata & Organic & - & {$[55]$} \\
\hline 62 & D. divaricata & Organic & - & {$[55]$} \\
\hline 63 & D. divaricata & Organic & - & {$[55]$} \\
\hline 64 & D. divaricata & Organic & - & {$[55]$} \\
\hline 65 & D. divaricata & Organic & - & {$[55]$} \\
\hline 66 & D. divaricata & Organic & - & {$[56]$} \\
\hline 67 & D. divaricata & Organic & - & {$[56]$} \\
\hline 68 & D. divaricata & Organic & - & {$[56]$} \\
\hline 69 & D. divaricata & Organic & - & {$[56]$} \\
\hline 70 & D. divaricata & Organic & - & {$[56]$} \\
\hline 71 & D. divaricata & Organic & - & {$[56]$} \\
\hline 72 & D. divaricata & Organic & - & {$[57]$} \\
\hline 73 & D. divaricata & Organic & - & {$[57]$} \\
\hline 74 & D. divaricata & Organic & - & {$[57]$} \\
\hline 75 & D. divaricata & Organic & - & {$[57]$} \\
\hline 76 & D. divaricata & $\mathrm{MeOH}$ & - & {$[58]$} \\
\hline 77 & D. divaricata & $\mathrm{MeOH}$ & - & [59] \\
\hline 78 & D. divaricata & $\mathrm{MeOH}$ & - & {$[60]$} \\
\hline 79 & D. divaricata & $\mathrm{MeOH}$ & - & {$[60]$} \\
\hline 80 & D. hoytii & $\mathrm{MeOH}$ & $\begin{array}{l}\alpha \text {-Glucosidase } \\
\text { inhibitor }\end{array}$ & {$[63]$} \\
\hline 81 & D. hoytii & $\mathrm{MeOH}$ & $\begin{array}{l}\alpha \text {-Glucosidase } \\
\text { inhibitor }\end{array}$ & {$[63]$} \\
\hline 82 & D. hoytii & $\mathrm{MeOH}$ & - & {$[63]$} \\
\hline 83 & D. hoytii & $\mathrm{MeOH}$ & - & {$[63]$} \\
\hline 84 & D. hoytii & $\mathrm{MeOH}$ & $\begin{array}{c}\alpha \text {-Glucosidase } \\
\text { inhibitor }\end{array}$ & {$[63]$} \\
\hline 85 & D. hoytii & $\mathrm{MeOH}$ & $\begin{array}{c}\alpha \text {-Glucosidase } \\
\text { inhibitor }\end{array}$ & {$[63]$} \\
\hline 86 & D. hoytii & $\mathrm{MeOH}$ & $\begin{array}{c}\alpha \text {-Glucosidase } \\
\text { inhibitor }\end{array}$ & {$[63]$} \\
\hline 87 & D. jolyana & $\mathrm{CH}_{2} \mathrm{Cl}_{2}-\mathrm{MeOH}(1: 1, \mathrm{v} / \mathrm{v})$ & Anticoagulant & {$[67]$} \\
\hline 88 & D. jolyana & $\mathrm{CH}_{2} \mathrm{Cl}_{2}-\mathrm{MeOH}(1: 1, \mathrm{v} / \mathrm{v})$ & Anticoagulant & {$[67]$} \\
\hline 89 & D. justii & $\mathrm{CH}_{3} \mathrm{COCH}_{3}$ & Anti-herbivory & [70] \\
\hline 90 & D. justii & $\mathrm{CH}_{3} \mathrm{COCH}_{3}$ & Anti-herbivory & {$[70]$} \\
\hline 91 & D. latiscula & Organic & Pheromone & {$[72]$} \\
\hline 92 & $\begin{array}{l}\text { D. latiscula } \\
\text { D. prolifera }\end{array}$ & Organic & Pheromone & [72] \\
\hline
\end{tabular}




\begin{tabular}{|c|c|c|c|c|}
\hline 93 & $\begin{array}{l}\text { D. latiscula } \\
\text { D. prolifera }\end{array}$ & Organic & Pheromone & {$[72]$} \\
\hline 94 & $\begin{array}{l}\text { D. latiscula } \\
\text { D. prolifera }\end{array}$ & Organic & Pheromone & {$[72]$} \\
\hline 95 & $\begin{array}{l}\text { D. latiscula } \\
\text { D. prolifera }\end{array}$ & Organic & Pheromone & {$[72]$} \\
\hline 96 & D. latiscula & Organic & - & {$[72]$} \\
\hline 97 & D. memberanacea & Organic & Anti-inflammatory & {$[81,82]$} \\
\hline 98 & D. memberanacea & Organic & - & {$[81]$} \\
\hline 99 & D. memberanacea & Organic & - & {$[81]$} \\
\hline 100 & D. memberanacea & $\mathrm{CH}_{2} \mathrm{Cl}_{2}-\mathrm{MeOH}(1: 1, \mathrm{v} / \mathrm{v})$ & Anti-inflammatory & {$[82]$} \\
\hline 101 & $\begin{array}{l}\text { D. memberanacea } D . \\
\text { plagiogramma }\end{array}$ & $\mathrm{CH}_{2} \mathrm{Cl}_{2}-\mathrm{MeOH}(1: 1, \mathrm{v} / \mathrm{v})$ & Anti-inflammatory & {$[82,86]$} \\
\hline 102 & D. memberanacea & $\mathrm{EtOH}$ & - & {$[83]$} \\
\hline 103 & D. memberanacea & EtOH & - & {$[83]$} \\
\hline 104 & D. memberanacea & $\mathrm{EtOH}$ & - & {$[83]$} \\
\hline 105 & D. memberanacea & $\mathrm{EtOH}$ & - & [83] \\
\hline 106 & D. memberanacea & EtOH & - & {$[83]$} \\
\hline 107 & D. plagiogramma & $\mathrm{CHCl}_{3}-\mathrm{MeOH}(1: 1, \mathrm{v} / \mathrm{v})$ & - & {$[86]$} \\
\hline 108 & D. plagiogramma & $\mathrm{CHCl}_{3}-\mathrm{MeOH}(1: 1, \mathrm{v} / \mathrm{v})$ & - & {$[86]$} \\
\hline 109 & D. plagiogramma & $\mathrm{CHCl}_{3}-\mathrm{MeOH}(1: 1, \mathrm{v} / \mathrm{v})$ & - & {$[86]$} \\
\hline 110 & $\begin{array}{l}\text { D. prolifera } \\
\text { D. undulata }\end{array}$ & Organic & - & {$[33]$} \\
\hline 111 & $\begin{array}{l}\text { D. prolifera } \\
\text { D. undulata }\end{array}$ & Organic & - & {$[33]$} \\
\hline 112 & $\begin{array}{l}\text { D. prolifera } \\
\text { D. undulata }\end{array}$ & Organic & - & {$[33,72]$} \\
\hline 113 & $\begin{array}{l}\text { D. prolifera } \\
\text { D. undulata }\end{array}$ & Organic & - & [33] \\
\hline 114 & D. undulata & $\mathrm{EtOH}$ & $\begin{array}{c}\text { Anti- } \\
\text { atherosclerotic }\end{array}$ & {$[96]$} \\
\hline 115 & D. undulata & $\mathrm{EtOH}$ & $\begin{array}{c}\text { Anti- } \\
\text { atherosclerotic }\end{array}$ & {$[96]$} \\
\hline 116 & D. undulata & $\mathrm{EtOH}$ & - & {$[96]$} \\
\hline 117 & D. undulata & $\mathrm{EtOH}$ & - & {$[96]$} \\
\hline 118 & D. undulata & $\mathrm{EtOH}$ & - & {$[96]$} \\
\hline 119 & D. undulata & $\mathrm{EtOH}$ & $\begin{array}{l}\text { Antiproliferative } \\
\text { PTP1B inhibitor }\end{array}$ & {$[96]$} \\
\hline 120 & D. undulata & $\mathrm{EtOH}$ & $\begin{array}{l}\text { Antiproliferative } \\
\text { PTP1B inhibitor }\end{array}$ & {$[96]$} \\
\hline 121 & D. undulata & $\mathrm{EtOH}$ & Antiproliferative & [96] \\
\hline 122 & D. undulata & $\mathrm{EtOH}$ & Antiproliferative & {$[96]$} \\
\hline 123 & D. undulata & $\mathrm{EtOH}$ & Antiproliferative & {$[96]$} \\
\hline 124 & D. undulata & $\mathrm{EtOH}$ & $\begin{array}{l}\text { Antiproliferative } \\
\text { PTP1B inhibitor }\end{array}$ & {$[96]$} \\
\hline
\end{tabular}




\begin{tabular}{|c|c|c|c|c|}
\hline $\mathbf{1 2 5}$ & D. undulata & EtOH & - & {$[96]$} \\
\hline $\mathbf{1 2 6}$ & D. undulata & EtOH & PTP1B inhibitor & {$[99]$} \\
\hline $\mathbf{1 2 7}$ & D. undulata & EtOH & PTP1B inhibitor & {$[99]$} \\
\hline $\mathbf{1 2 8}$ & D. undulata & EtOH & PTP1B inhibitor & {$[99]$} \\
\hline $\mathbf{1 2 9}$ & D. undulata & EtOH & PTP1B inhibitor & {$[99]$} \\
\hline $\mathbf{1 3 0}$ & D. undulata & EtOH & PTP1B inhibitor & {$[99]$} \\
\hline $\mathbf{1 3 1}$ & D. undulata & EtOH & - & {$[99]$} \\
\hline $\mathbf{1 3 2}$ & D. undulata & EtOH & - & {$[99]$} \\
\hline $\mathbf{1 3 3}$ & D. undulata & EtOH & $\begin{array}{c}\text { Anti- } \\
\text { atherosclerotic }\end{array}$ & {$[99]$} \\
\hline $\mathbf{1 3 4}$ & D. undulata & $\mathrm{MeOH}$ & Algicidal & {$[100]$} \\
\hline $\mathbf{1 3 5}$ & D. undulata & $\mathrm{MeOH}$ & Algicidal & Feuroprotective \\
& & Fungitoxic & {$[100,101,109]$} \\
\hline $\mathbf{1 3 6}$ & D. undulata & $\mathrm{MeOH}$ & $\begin{array}{c}\text { Algicidal } \\
\text { Fntioxidant }\end{array}$ & {$[100,109]$} \\
\hline $\mathbf{1 3 7}$ & D. undulata & $\mathrm{MeOH}$ & Algicidal & {$[100]$} \\
\hline $\mathbf{1 3 8}$ & D. undulata & $\mathrm{MeOH}$ & Algicidal & {$[100]$} \\
\hline $\mathbf{1 3 9}$ & D. undulata & $\mathrm{MeOH}$ & Antioxidant & {$[100,102,104]$} \\
\hline $\mathbf{1 4 0}$ & D. undulata & $\mathrm{MeOH}$ & Algicidal & {$[100]$} \\
\hline $\mathbf{1 4 1}$ & D. undulata & $\mathrm{MeOH}$ & Antioxidant & {$[102]$} \\
\hline $\mathbf{1 4 2}$ & D. undulata & $\mathrm{MeOH}$ & Antioxidant & {$[102]$} \\
\hline $\mathbf{1 4 3}$ & D. undulata & $\mathrm{MeOH}$ & Feeding-deterrent & {$[103]$} \\
\hline $\mathbf{1 4 4}$ & D. undulata & Organic & - & {$[104]$} \\
\hline
\end{tabular}

Table 2: Biological assays related to therapeutic potential of Dictyopteris Extracts.

\begin{tabular}{|c|c|c|c|c|}
\hline $\begin{array}{c}\text { Extract } \\
\text { number }\end{array}$ & Species & Solvent & Activity & $\begin{array}{c}\text { Referenc } \\
\text { es }\end{array}$ \\
\hline $\mathbf{1}$ & D. acrostichoides & $\begin{array}{c}\text { n-Hexane and } \\
\text { dichloromethane }\end{array}$ & Anti-microbial & {$[8]$} \\
\hline $\mathbf{2}$ & D. australis & Methanol & Antioxidant Cytotoxic & {$[17]$} \\
\hline $\mathbf{3}$ & D. delicatula & Methanol & Antioxidant Cytotoxic & {$[17]$} \\
\hline $\mathbf{4}$ & D. delicatula & Aqueous & $\begin{array}{c}\text { Antioxidant } \\
\text { Antiproliferative } \\
\text { Anticoagulant }\end{array}$ & {$[18,19]$} \\
\hline $\mathbf{5}$ & D. delicatula & $\mathrm{CH}_{2} \mathrm{Cl}_{2}$ - MeOH $(1: 1, \mathrm{v} / \mathrm{v})$ & Antioxidant & {$[20]$} \\
\hline $\mathbf{6}$ & D. delicatula & Aqueous & Antiparasitic & {$[22]$} \\
\hline $\mathbf{7}$ & D. divaricate & Aqueous & Antioxidant Immune & {$[25]$} \\
\hline $\mathbf{8}$ & D. divaricata & Ethyl acetate & Anti-inflammatory & {$[26]$} \\
\hline
\end{tabular}




\begin{tabular}{|c|c|c|c|c|}
\hline 9 & D. divaricata & Ethyl acetate & Antiproliferative & [48] \\
\hline 10 & D. divaricate & Hexane & Antiproliferative & \\
\hline 11 & D. divaricate & $\mathrm{CHCl}_{3}-\mathrm{MeOH}(1: 1, \mathrm{v} / \mathrm{v})$ & $\alpha$-Glucosidase inhibitor & {$[28]$} \\
\hline 12 & D. divaricate & Aqueous & Neuroprotection & [29] \\
\hline 13 & D. jamaicensis & Aqueous & Anti-trypanosomal & {$[64]$} \\
\hline 14 & D. jamaicensis & $\mathrm{CHCl}_{3}-\mathrm{MeOH}(1: 1, \mathrm{v} / \mathrm{v})$ & Anti-microbial & {$[65]$} \\
\hline 15 & D. jolyana & $\mathrm{CH}_{2} \mathrm{Cl}_{2}-\mathrm{MeOH}(1: 1, \mathrm{v} / \mathrm{v})$ & Anticoagulant & [67] \\
\hline 16 & D. justii & Aqueous & $\begin{array}{c}\text { Antioxidant inhibitor of } \\
\text { the formation of oxalate } \\
\text { crystals. } \\
\text { Anticoagulant }\end{array}$ & {$[68,69]$} \\
\hline 17 & D. justii & $\mathrm{CHCl}_{3}-\mathrm{MeOH}(1: 1, \mathrm{v} / \mathrm{v})$ & Anti-microbial & {$[65]$} \\
\hline 18 & D. longifolia & Ethanol & Anti-microbial & {$[75]$} \\
\hline 19 & D. membranacea & Cyclohexane & Anti-microbial & {$[76]$} \\
\hline 20 & D. memberanacea & Aqueous and organic & $\begin{array}{c}\text { Anti-microbial } \\
\text { Antioxidant } \\
\text { Anti-inflammatory }\end{array}$ & [77] \\
\hline 21 & D. memberanacea & Aqueous & Gastroprotective & {$[78]$} \\
\hline 22 & D. memberanacea & Acetone and ethanol & $\begin{array}{c}\text { Antibacterial } \\
\text { Antifungal } \\
\text { Antitubercular }\end{array}$ & [79] \\
\hline 23 & D. memberanacea & Methanol & Anti-microbial & {$[80]$} \\
\hline 24 & D. memberanacea & Ethanol & $\begin{array}{c}\text { Anti-microbial } \\
\text { Antioxidant } \\
\text { Anti-inflammatory } \\
\end{array}$ & [83] \\
\hline 25 & D. polypodioides & Aqueous & Antiproliferative & [88] \\
\hline 26 & D. polypodioides & Methanol and ethyl acetate & Anti-microbial & [89] \\
\hline 27 & D. polypodioides & Organic & Anti-microbial & {$[90]$} \\
\hline 28 & D. prolifera & Ethanol & $\alpha$-Glucosidase inhibitor & [93] \\
\hline 29 & D. prolifera & Ethyl acetate & Anti-inflammatory & {$[26]$} \\
\hline 30 & D. undulata & Ethanol & Antiproliferative & [94] \\
\hline
\end{tabular}

\section{Acknowledgments}

We would like to thank Minia University and South Valley University for supporting this work.

\section{References}

1. Rushdi, M. I., et al. Nat. Prod. Res. 2020, 1-19. DOI: https://doi.org/10.1080/14786419.2020.1731741

2. Nishibayashi, T.; Inoh, S. Bot. Mag. (Tokyo). 1959, 72, 261-268. 
3. Guiry, M.; Guiry, G. AlgaeBase, NUI, Galway. 2021. https://www.algaebase.org/

4. Moore, R. E. Acc. Chem. Res. 1977, 10, 40-47. DOI: https://doi.org/10.1021/ar50110a002

5. Boland, W. Proc. Natl. Acad. Sci. U.S.A. 1995, 92, 37-43. DOI: https://doi.org/10.1073/pnas.92.1.37

6. Wirth, D., et al. Helv. Chim. Acta. 1992, 75, 734-744. DOI: https://doi.org/10.1002/hlca.19920750309

7. Lever, J., et al. Mar. Drugs. 2020, 18, 142. DOI: https://doi.org/10.3390/md18030142

8. Isroni, W.; Bahri, A. S. IOP Conf. Ser. Earth Environ. Sci. 2020, 493, 012014. DOI: https://doi.org/10.1088/1755-1315/493/1/012014

9. Moore, R. E.; Pettus, J. A. Tetrahedron Lett. 1968, 4787-4790. DOI: https://doi.org/10.1016/S00404039(00)75957-0

10. Moore, R. E.; Yost, G. J. Chem. Soc. Chem. Commun. 1973, 937-938. DOI: https://doi.org/10.1039/C39730000937

11. Moore, R. E.; Pettus, J. A.; Mistysyn, J. J. Org. Chem. 1974, 39, 2201-2207. DOI: https://doi.org/10.1021/jo00929a013

12. Pickenhagen, W., et al. Helv. Chim. Acta. 1973, 56, 1868-1874. DOI: https://doi.org/10.1002/hlca.19730560607

13. Moore, R. E. J. Chem. Soc., Chem. Commun. 1971, 1168-1169. DOI https://doi.org/10.1039/c2971001168b

14. Schotten, T.; Boland, W.; Jaenicke, L. Tetrahedron Lett. 1986, 27, 2349-2352. DOI: https://doi.org/10.1016/S0040-4039(00)84526-8

15. Morio, A.; Katsuhiro, K.; Hisashi, T. Bull. Chem. Soc. Jpn. 1994, 67, 1141-1146.

16. Gosch, B. J., et al. J. Appl. Phycol. 2015, 27, 1607-1622. DOI: https://doi.org/10.1007/s10811-0140474-4

17. Vinayak, R. C.; Sabu, A.; Chatterji, A. J. Evid.-Based Integr. Med. 2011, 2011, 673083. DOI: https://doi.org/10.1093/ecam/neq024

18. Costa, L. S., et al. Biomed. Pharmacother. 2010, 64, 21-28. DOI: https://doi.org/10.1016/j.biopha.2009.03.005

19. Magalhaes, K. D., et al. Int. J. Mol. Sci. 2011, 12, 3352-3365. DOI: https://doi.org/10.3390/ijms12053352

20. Rodrigues, S., et al. Biotechnol. Appl. Biochem. 2020, 192, 665-679. DOI: https://doi.org/10.1007/s12010-020-03344-4

21.König, G. M.; Wright, A. D. Magn. Reson. Chem. 1995, 33, 178-183. DOI: https://doi.org/10.1016/0031-9422(89)80070-6

22. Hutson, K. S., et al. Int. J. Parasitol. Parasites. 2012, 42, 1135-1141. DOI https://doi.org/10.1016/j.ijpara.2012.09.007

23. Sousa, M. B. d., et al. Food Sci. Biotechnol. 2008, 28, 953-958. DOI: https://doi.org/10.1590/S010120612008000400030

24. Khotimchenko, S. V. Phytochemistry. 1995, 38, 1411-1415. DOI: https://doi.org/10.1016/00319422(94)00819-F

25. Cui, Y., et al. Int. J. Biol. Macromol. 2018, 117, 256-263. DOI: https://doi.org/10.1016/j.ijbiomac.2018.05.134

26. Yang, E.-J., et al. Asian Pac. J. Trop. Biomed. 2014, 4, 529-537. DOI: https://doi.org/10.12980/APJTB.4.2014C1099

27. Xu, N., et al. J. Appl. Phycol. 2004, 16, 451-456. DOI: https://doi.org/10.1007/s10811-004-5508-x 28. Xiancui, L., et al. J. Oceanol. Limnol. 2005, 23, 354-356. DOI: https://doi.org/10.1007/BF02847160 29. Jeon, H., et al. Molecules. 2019, 24, 1420-3049. DOI: https://doi.org/10.3390/molecules24020276 
30. Qiao, Y.-Y., et al. Mar. Drugs. 2009, 7, 600-604. DOI: https://doi.org/10.3390/md7040600

31. Suzuki, M.; Kowata, N.; Kurosawa, E. Bull. Chem. Soc. Jpn. 1981, 54, 2366-2368, DOI: https://doi.org/10.1246/bcsj.54.2366

32. Hodgson, D. M.; Salik, S.; Fox, D. J. J. Org. Chem. 2010, 75, 2157-2168. DOI: https://doi.org/10.1021/jo9022974

33. Kajiwara, T., et al. Phytochemistry. 1989, 28, 636-639. DOI: https://doi.org/10.1016/00319422(89)80070-6

34. McMurry, J. E.; Kočovský, P. Tetrahedron Lett. 1985, 26, 2171-2172. DOI: https://doi.org/10.1016/S0040-4039(00)98953-6

35. Yao, Y.-Q., et al. Cancer Lett. 2008, 264, 127-134. DOI: https://doi.org/10.1016/j.canlet.2008.01.049

36. Yang, D., et al. Am. J. Cancer Res. 2021, 11, 370-388.

37. Song, F. H., et al. J. Asian Nat. Prod. Res. 2005, 7, 777-781. DOI: https://doi.org/10.1080/1028602032000169532

38. Xu, X.-1., et al. Mar. Sci. 2012, 36, 81-84.

39. Park, S. H., et al. Int. J. Mol. Sci. 2019, 20, 651. DOI: https://doi.org/10.3390/ijms20030651

40. Yang, H. H., et al. Arch. Pharm. Res. 2015, 38, 876-884. DOI: https://doi.org/10.1007/s12272-014$\underline{0435-0}$

41. Vizetto-Duarte, C., et al. Phytomedicine. 2016, 23, 550-557. DOI: https://doi.org/10.1016/j.phymed.2016.02.008

42. Song, F. H., et al. Zhongguo Zhong Yao Za Zhi. 2006, 31, 125-8. DOI: http://www.ncbi.nlm.nih.gov/pubmed/16570798

43. Lee, J. M., et al. J. Fish. Aquat. Sci. 2020, 23, 1-6.

44. Hwang, E., et al. Mar. Biotechnol. 2014, 16, 361-370. DOI: https://doi.org/10.1007/s10126-013-95548

45. Rushdi, M. I., et al. RSC Adv. 2020, 10, 24951-24972. DOI: https://doi.org/10.1039/D0RA03576A

46. Jiang, H., et al. Oncol. Lett. 2018, 15, 3458-3463. DOI: https://doi.org/10.3892/ol.2018.7769

47. Song, Y., et al. Food Sci. Biotechnol. 2017, 26, 489-494. DOI: https://doi.org/10.1007/s10068-0170067-5

48. Kim, K., et al. Int. J. Pharmacol. 2009, 5, 298-306

49. Rushdi, M. I., et al. S. Afr. J. Bot. 2021, 141, 37-48. DOI: https://doi.org/10.1016/j.sajb.2021.04.018

50. Cho, J.-Y., et al. Biosci. Biotechnol. Biochem. 1998, 62, 2273-2276. DOI: https://doi.org/10.1271/bbb.62.2273

51.Peungvicha, P., et al. J. Ethnopharmacol. 1998, 62, 79-84. DOI: https://doi.org/10.1016/S0378$\underline{8741(98) 00061-0}$

52. Wen, W., et al. Molecules. 2009, 14, 2273-7. DOI: http://www.ncbi.nlm.nih.gov/pubmed/19553898

53. Ji, N. Y., et al. Mar. Drugs. 2009, 7, 355-60. DOI: https://doi.org/10.3390/md7030355

54. Etsuro, K., et al. Bull. Chem. Soc. Jpn. 1966, 39, 2509-2512. DOI: https://doi.org/10.1246/bcsj.39.2509

55. Song, F., et al. J. Nat. Prod. 2006, 69, 1261-1266. DOI: https://doi.org/10.1021/np060076u

56. Song, F., et al. J. Nat. Prod. 2004, 67, 1644-1649. DOI: https://doi.org/10.1021/np040099d

57. Song, F., et al. J. Nat. Prod. 2005, 68, 1309-1313. DOI: https://doi.org/10.1021/np040227y

58. Minoru, S., et al. Chem. Lett. 1990, 19, 2187-2190.

59. Segawa, M.; Yamano, K.; Shirahama, H. Phytochemistry. 1990, 29, 973-974. DOI: https://doi.org/10.1016/0031-9422(90)80058-O

60. Toshi, I.; Koji, Y.; Tadashi, M. Bull. Chem. Soc. Jpn. 1964, 37, 1053-1055. DOI: https://doi.org/10.1246/bcsj.37.1053 
61. Hay, M. E., et al. Mar. Ecol. . 1988, 48, 185-192.

62. Schnitzler, I., et al. Oecologia. 2001, 126, 515-521. DOI: https://doi.org/10.1007/s004420000546

63. Ur Rehman, N., et al. Mar. Drugs. 2019, 17, 666. DOI: https://doi.org/10.3390/md17120666

64. León-Deniz, L. V., et al. Pharm. Biol. 2009, 47, 864-871.

65. Ballantine, D. L., et al. Hydrobiologia. 1987, 151, 463-469.

66. Bianco, É., et al. Molecules. 2013, 18, 5761-5778, DOI: https://doi.org/10.3390/molecules18055761

67. Syracuse, $\quad$ S. $\quad$ M. Repositório Institucional da UFSC. 2018, https://repositorio.ufsc.br/handle/123456789/191938

68. Melo, K. R., et al. Molecules. 2013, 18, 14543-63. DOI: https://doi.org/10.3390/molecules181214543 69. Melo, K. R. T., et al. Holos. 2012, 1, 29-40.

70. Teixeira, V., et al. Nat. Prod. Commun. 2006, 1, 293- 297.

71. Rushdi, M. I., et al. S. Afr. J. Bot. 2020, 132, 226-241. DOI: https://doi.org/10.1016/j.sajb.2020.04.031

72. Yamamoto, Y., et al. Z. Naturforsch. C. 2001, 56, 6-12. DOI: https://doi.org/10.1515/znc-2001-1-202

73. Kajiwara, T., et al. Z. Naturforsch. C. 2003, 58, 109. DOI: https://doi.org/10.1515/znc-2003-1-219

74. Yamada, K.; Tan, H.; Hirota, K. Tetrahedron Lett. 1980, 21, 4873-4874. DOI: https://doi.org/10.1016/0040-4039(80)80163-8

75. Vlachos, V.; Critchley, A.; Von Holy, A. Bot. Mar. 1999, 42, 165-173. DOI https://doi.org/10.1515/BOT.1999.019

76. Khallil, A.; Daghman, I.; FadyAA. J. Microbiol. Mod. Tech. 2015, 1, 1- 9

77. Aoun, Z. B.; Said, R. B.; Farhat, F. Bot. Mar. 2010, 53, 259-264. DOI: https://doi.org/10.1515/BOT.2010.027

78. Ammar, H. H., et al. Food Chem. 2018, 239, 165-171. DOI: https://doi.org/10.1016/j.foodchem.2017.06.108

79. Akremi, N., et al. S. Afr. J. Bot. 2017, 108, 308-314. DOI: https://doi.org/10.1016/j.sajb.2016.08.009

80. Ozdemir, G., et al. Pharm. Biol. 2006, 44, 183-188. DOI: https://doi.org/10.1080/13880200600685949

81. Dimou, M., et al. J. Nat. Prod. 2016, 79, 584-589. DOI: https://doi.org/10.1021/acs.jnatprod.5b01031

82. Daskalaki, M. G., et al. Mar. Drugs. 2020, 18, 527. DOI: https://doi.org/10.3390/md18110527

83. AliAboutabl, E., et al. Med. Aromat. Plant. Sci. Biotechnol. 2010, 4, 41-48

84. Hofmann, M.; Eichenberger, W. Plant. Cell. .Physiol. 1998, 39, 508-515

85. Schmid, M., et al. Food Chem. 2018, 265, 70-77. DOI: https://doi.org/10.1016/j.foodchem.2018.05.060

86. Roller, P.; Au, K.; Moore, R. E. Chem. Commun. 1971, 503-504. DOI: https://doi.org/10.1039/c29710000503

87. Percival, E.; Anisur Rahman, M.; Weigel, H. Phytochemistry. 1981, 20, 1579-1582. DOI: https://doi.org/10.1016/S0031-9422(00)98535-2

88. Sokolova, R. V., et al. Chem. Nat. Compd. 2011, 47, 329-334. DOI: https://doi.org/10.1007/s10600011-9925-1

89. Kolsi, R. B. A., et al. J. Pharmacogn. Phytochem. 2017, 6, 109-113

90. Riad, N., et al. Microchem. J. 2020, 152, 104415. DOI: https://doi.org/10.1016/j.microc.2019.104415

91. Yamada, K., et al. Tetrahedron. 1986, 42, 3775-3780. DOI: https://doi.org/10.1016/S00404020(01)87531-1

92. Yamada, K.; Tan, H.; Tatematsu, H. J. Chem. Soc., Chem. Commun. 1979, 13, 572-573. DOI: https://doi.org/10.1039/C39790000572

93. Jeong, S.-Y., et al. Nat. Prod. Sci. 2012, 18, 130-136. 
94. Kang, K. A., et al. J. Cancer Prev. 2014, 19, 118-124. DOI: https://doi.org/10.15430/JCP.2014.19.2.118

95. Feng, M.-T., et al. Phytochemistry. 2018, 146, 25-35. DOI: https://doi.org/10.1016/j.phytochem.2017.11.013

96. Chen, Z., et al. J. Agric. Food Chem. 2014, 62, 6130-6137.

97. Yang, F., et al. Fitoterapia. 2018, 130, 241-246.

98. Breuer, O., et al. Eur. J. Biochem. 1993, 215, 705-710. DOI: https://doi.org/10.1111/j.14321033.1993.tb18082.x

99. Millanvoye-Van Brussel, E., et al. Biochem. J. 2004, 380, 533-539. DOI: https://doi.org/10.1042/bj20040069

100. Ishibashi, F., et al. Biosci. Biotechnol. Biochem. 2013, 77, 1120-1122. DOI: https://doi.org/10.1271/bbb.130018

101. Shimizu, H., et al. Biochem. Biophys. Res. Commun. 2015, 457, 718-722. DOI: https://doi.org/10.1016/j.bbrc.2015.01.059

102. Kumagai, M., et al. Molecules. 2018, 23, 1214. DOI: https://doi.org/10.3390/molecules23051214

103. Kurata, K.; Taniguchi, K.; Suzuki, M. Phytochemistry. 1996, 41, 749-752. DOI: https://doi.org/10.1016/0031-9422(95)00651-6

104. Dave, M.-N., et al. Heterocycles. 1984, 22, 2301-2307

105. Wang, H.-S., et al. Eur. J. Org. Chem. 2018, 2018, 915-925. DOI: https://doi.org/10.1002/ejoc.201800026

106. Laube, T., et al. Tetrahedron. 2002, 58, 4299-4309. DOI: https://doi.org/10.1016/S00404020(02)00346-0

107. Shaikh, H. S. N.a. J. Adv. Res. Rev. 2020, 3, 169-181.

108. Fenical, W., et al. Phytochemistry. 1972, 11, 1161-1163. DOI: https://doi.org/10.1016/S00319422(00)88472-1

109. Fenical, W., et al. J. Org. Chem. 1973, 38, 2383-2386. DOI: https://doi.org/10.1021/jo00953a022

110. Yamada, S., et al. PloS one. 2014, 9, e113509. DOI: https://doi.org/10.1371/journal.pone.0113509 